\title{
Monetary Policy Regime Change and Regional Inflation Dynamics: Looking through the Lens of Sector-Level Data for Korea
}

\author{
Chi-Young Choi* \\ Joo Yong Lee** \\ Róisín O’Sullivan***
}

The views expressed herein are those of the authors and do not necessarily reflect the official views of the Bank of Korea. When reporting or citing this paper, the authors' name should always be stated explicitly.

\footnotetext{
* Corresponding author, Economics Department, University of Texas at Arlington, E-mail: cychoi@uta.edu

** Economic Research Institute, The Bank of Korea, E-mail: ljy@bok.or.kr

*** Department of Economics, Smith College
} 


\section{Contents}

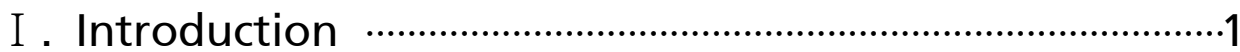

II. The Data and Preliminary Analysis ……………............ 5

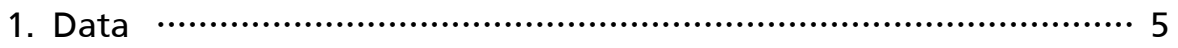

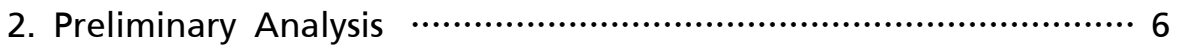

III. Econometric Analysis of City-Level Inflation by Sector $\cdot 12$

1. Structural Changes in Inflation …………………………..... 12

2. Dynamic Properties of Inflation Series ………….................... 15

3. Impact of IT on Spatial Co-Movements of Inflation ………..... 21

4. Common Factor Model Analysis …………………………….... 26

5. Impact of IT on Intercity Relative Prices ………..................... 32

6. Price Stickiness as a Potential Factor behind the Sectoral Heterogeneity ……................................................................ 35

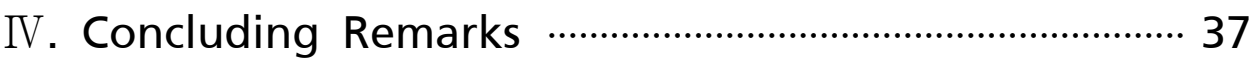

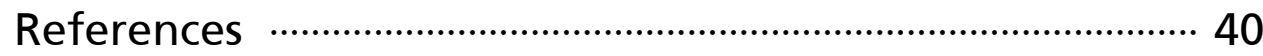

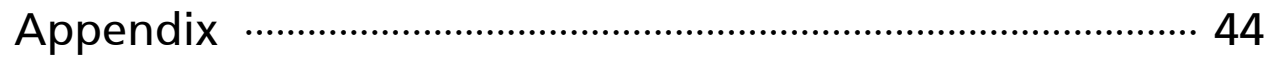




\section{Monetary Policy Regime Change and Regional Inflation Dynamics: Looking through the Lens of Sector-Level Data for Korea}

This paper explores the impact of the adoption of inflation targeting (IT) on the dynamics of city-level inflation in Korea using both aggregate and sector-level data. When looking at aggregate regional inflation, we find that the mean, volatility and persistence fell in all cities in the wake of the monetary policy regime change, consistent with other evidence in the literature. We also note a narrowing of the dispersion of regional inflation across cities and a greater degree of regional co-movement.

Delving more deeply into the disaggregate data reveals additional insights however. For most of the changes we observe in the dynamics of regional inflation, we find that the aggregate effects are being driven primarily by sectors that fall into the 'Services' category. We posit that the impact of better anchored inflationary expectations is primarily on the less-traded services sectors of the economy, where the domestic monetary policy framework has a relatively larger influence compared with globally-traded commodities.

When it comes to the increased co-movement observed across regions under IT regime, however, it is the 'Commodities' sectors rather than 'Services' that are responsible, probably because services inflation becomes relatively more influenced by local factors once it has stabilized within the target range. We show that this sectoral heterogeneity can be explained by the difference in price stickiness such that sectors in which prices are adjusted less frequently tend to have a larger response under the new monetary policy regime.

Keywords: Regional inflation, Inflation targeting (IT), Inflation dynamics, Heterogeneity, Korean cities, Disaggregate CPI.

JEL Classification: E31, E52, E58 


\section{I . Introduction}

There is a large literature examining the impact of inflation targeting (IT) on inflation performance at the aggregate level (e.g., Mishkin and Schmidt-Hebbel 2007, Choi et al. 2011). The basic result in the empirical literature is that the adoption of IT is typically followed by a fall in both the level and volatility of macroeconomic measures of inflation such as the consumer price index, especially in emerging economies. Moreover, a fall in inflation persistence has often been noticed in IT countries, probably due to better-anchored inflationary expectations after an explicit announcement of an inflation target in the medium term. There is ample empirical evidence, however, of a significant degree of heterogeneity in the inflation dynamics of different economic sectors and different geographic regions (e.g., Bils and Klenow 2004, Beck et al. 2009). In fact, researchers looking at the impact of monetary policy actions have found substantially different responses to a common monetary policy across regions, with these differences often associated with regional differences in sectoral composition (e.g., Carlino and DeFina 1998). Furthermore, recent studies using sectoral data have documented heterogeneous effects of a switch in monetary policy regime on the dynamics of disaggregate inflation (e.g., Choi and O'Sullivan 2013). In light of the possible interface between sectoral and regional effects, it would be instructive to examine the impact of a change in the monetary policy regime using data disaggregated along both these dimensions in identifying the channels through which the adoption of IT might influence the macro economy. Given that large and persistent differences in regional inflation dynamics poses challenges for a one-size-fits-all monetary policy, it is important for policy makers to understand what drives inflation differentials across various regions within a nation. Since the heterogeneity of regional inflation dynamics may stem from the segmentation of labor and product markets, examining this heterogeneity in the context of differences in behavior across products or sectors seems promising.

The main objective of this study is to explore the responses of inflation to a change in monetary policy regime at the disaggregate level in terms of both sectors and regions. To this end, we study the case of Korea with its official 
adoption of IT in 1998.1) As an emerging market economy, Korea is an interesting country to study, especially given its degree of openness and its potential role as a case study for other Asian economies considering the adoption of IT or that recently adopted IT such as India. Moreover, the availability of city-level inflation data for various sectors over a reasonably long time span permits a rich analysis of the issues at hand, including the analysis of regional responses across various sectors. Although this is not the first study of the impact of IT adoption on Korea, we are not aware of another study that looks simultaneously at the variation across sectors and regions of the impact of the monetary regime change. ${ }^{2)}$ Kim and Park (2006) provide an excellent general overview of the effect of IT adoption on Korea, but they use aggregate headline inflation only. Tillmann (2013) studies extensively the impact of IT adoption at the regional level in Korea, but focuses on the response of inflation persistence at the aggregate level without considering sectoral-level developments. In general, these studies conclude that IT was successful in stabilizing inflation in Korea, but not much is known about the extent to which this stabilization was felt broadly at a disaggregate level. It seems therefore a step in the right direction to extend their analyses by looking at the behavior of regional price data across different sectors, especially in light of the growing interest in sectoral heterogeneity in recent studies (e.g., Carvalho and Nechio 2011) and the potential link between inflation differentials and welfare costs (e.g., Beck et al. 2009). In addition, our focus on geographic dispersion of inflation measures may help us gain additional insight on the regional integration in Korea, especially given the absence of city-level output data. That is, by investigating the impact of IT adoption on inflation measures for 30 cities across Korea, we attempt to shed light on whether the new monetary regime had an influence on intra-national economic integration.

1) Korea formally adopted inflation targeting in late 1997 when the Bank of Korea (BOK) law was revised to explicitly announce a target rate of inflation from April 1998 (see Kim and Park 2006). At the outset, the country followed a version of IT known as flexible inflation targeting, with M3 still being used as an intermediate target, prior to becoming a "full-fledged" inflation targeter in 2001. Given that the impact on inflationary expectation formation is most likely to have occurred from the outset, we use April 1998 as the formal adoption date for our analysis.

2) A similar line of research looking at both regional and sectoral disaggregation has been conducted in a cross-national context among EU countries (e.g., Lunnemann and Matha 2004), which differs from our focus on intra-national analysis. 
Our analysis based on disaggregate data confirms that the adoption of IT in Korea had a significant effect on regional inflation dynamics, but in a markedly differing manner across sectors. The heterogeneity observed was much more pronounced across sectors than across regions. In sectors where price movements are dominated by quite forward-looking price-setting behavior, better anchoring of inflationary expectations with the adoption of IT played a bigger role and resulted in a greater response to the regime change. In contrast, in other sectors where prices are largely determined in global markets, inflation dynamics are governed primarily by external shocks and therefore are less responsive to the change in the domestic monetary policy regime. Between the broad sectoral sub-aggregates of commodities versus services, for instance, the change in both the level and volatility of inflation in the wake of IT adoption was much greater for services. For some commodity sectors, city-level inflation rates often fluctuated far outside the target range. This may reflect fundamental differences in the major determinants of the inflation processes in the various sectors. At the regional level, we observe an overall decline in the cross-city dispersion of inflation but, again, there is considerable heterogeneity across sectors.

We also find that the IT adoption in Korea appears to have brought about changes in how inflationary expectations are formed and, in particular, how well-anchored these expectations are, as reflected in measures of inflation persistence. As claimed by Benati (2008), the implementation of a stable monetary policy regime with a well-defined nominal anchor, such as IT, contributes to a decrease in inflation persistence in most developed countries. This finding is borne out in the aggregate data for Korea, with persistence falling after the adoption of IT. There was a wide variation across sectors, however, in the response of the city-level inflation, with inflation in some sectors becoming more persistent under IT. The cross-sector heterogeneity is also evident in measures of co-movements and synchronization among regional inflation rates based on spatial correlation and inter-city relative prices. This emphasizes the potential for gaining a richer understanding of the impact of IT adoption by looking beyond aggregate measures of inflation.

We further explore whether regional inflation is better explained by nationwide factors than city-specific factors by employing a factor model framework in which 
city-level inflation rates are decomposed into a common component, governed by a common national factor that drives co-movements in inflation across cities, and an idiosyncratic component specific to each city. In aggregate inflation, we find that about $75 \%$ of the variability of regional inflation can be explained by the common factor over the entire sample period, suggesting important commonality across cities in Korea. More importantly, the share of the common factor has slightly increased after the adoption of IT. This indicates that a larger part of the variation in regional inflation is explained by the national factor under the IT regime. At the disaggregate level, however, the share of the common factor varies widely across CPI sectors and it rose for some sectors in the wake of IT adoption, but fell for others. This implies that, under the new monetary regime, common national shocks played a more dominant role in the dynamics of inflation for some sectors but not for others. This may reflect the fact that regional inflation in some sectors responded less synchronously to aggregate shocks after IT as they believed the central bank would offset the impact of exogenous disturbances, while in other sectors the response of regional inflation to common national shocks becomes more homogeneous in the new monetary regime. When all sectors are taken into account, the share of common factor is below 15 percent, which is similar to what Boivin et al. (2009) found in the US data and Choi and O'Sullivan (2013) in the Canadian data. Moreover, this share is lower in the post-IT period, dropping from $13.3 \%$ to merely $10.0 \%$, indicating that the common factor explain merely 10 percent of the variance of sectoral inflation under the IT regime. This is because sectoral inflation became less responsive to aggregate macro shocks as inflation expectations became better anchored under the IT regime and hence sector-specific shocks play a more dominant role in accounting for the variance in city-level inflation. We also find that the nationwide common factor has significantly different effects across cities in each CPI sector.

The pervasive evidence of heterogeneous responses in regional inflation to the adoption of IT across various sectors of the economy naturally raises the question as to what underlying sectoral characteristics might account for the different responses to the change in monetary regime. In turn, given the variation in the sectoral make-up of different regions of the country, sector-specific characteristics may also contribute to understanding variation in aggregate regional inflation. In 
view of the central role afforded to price stickiness in many theoretical models (e.g. Dornbusch 1976, Aoki 2001), we relate the extent to which prices are sticky in a particular sector to the nature of that sector's response to the adoption of IT. We find that sectors with a higher degree of price stickiness experience a larger decline in inflation persistence under the IT regime, in line with the findings by Choi and O'Sullivan (2013) for Canada. This may reflect the more forward-looking behavior of firms in these sectors who are therefore more sensitive to a change in the monetary regime that impacts the formation of inflationary expectations.

The remainder of the paper is laid out as follows. Section 2 describes the data and provides a preliminary analysis of the heterogeneous patterns observed in the sub-aggregate inflation series. Section 3 extends this analysis using more formal econometric techniques, including structural break tests, an examination of the dynamic properties of the inflation series, and a look at spatial correlation based on a modified Moran's I. This section also delves into the heterogeneous response of regional inflation within the framework of common factor model analysis and via an examination of the behavior of inter-city relative prices. This is followed by an analysis of the role of price stickiness as a potential source of the observed heterogeneity. Section 4 concludes. The Appendix contains a detailed description of the data.

\section{II . The Data and Preliminary Analysis}

\section{Data}

We use monthly indices of the overall consumer price index and its subaggregates for 30 cities $^{3)}$ in Korea. We focus on two levels of disaggregation of the

3) The cities included are: Andong (AND), Boryeong (BOR), Bucheon (BCN), Busan (BSN), Cheonan (CAN), Cheongju (CHE), Chuncheon (CCN), Chungju (CHU), Daegu (DGU), Dae- jeon (DJN), Gangneung (GNG), Gumi (GUM), Gunsan (GSN), Gwangju (GWJ), Gyeongju (GNJ), Incheon (ICN), Jeju-do (JJD), Jeonju (JEN), Jinju (JIN), Mokpo (MKP), Namwon (NWN), Pohang (PHN), Seongnam (SGN), Seoul (SEL), Suncheon (SCN), Suwon (SWN), Uijeongbu (UJB), Ulsan,(ULS), Wonju (WNJ), and Yeosu (YSU). 
CPI here; one that distinguishes between 'Commodities' and 'Services' and the other with a finer-level of disaggregation that includes 12 one-digit sub-categories. Our choice of CPI sectors was motivated by the desire to get sufficiently long continuous data series for monthly price indices in as many cities as possible to facilitate our regional analysis. The underlying data have been collected from the Korean Statistical Information Service (KOSIS) homepage at http://kosis.kr/. The Appendix Tables present sectoral and city-level information for the sub-aggregate series that span January 1990 to August 2014, resulting in 296 monthly observations for each of the 30 cities across 14 CPI sectors. In our analysis, we consider both the annualized monthly percentage change and 12-month inflation rates in the consumer price index and its components, after seasonally adjusting the indices using the Census X12-ARIMA method. Unless noted otherwise, we concentrate on the annualized monthly inflation rates.

From Table A.3, it is evident that the weights attributed to the disaggregate CPI series vary to a non-negligible degree across cities: for example, the weight for 'Commodities' (Item 1) ranges from 35.3\%-47.3\% with 'Services' (Item 2) accounting for the balance. At the finer level of disaggregation, a relatively wide range is seen in the weight given to 'Rental for housing' (Item 12), as might be expected, with the weight of 150.1 in Seoul (SEL) almost four times as large as that in Suncheon (SCN).

\section{Preliminary Analysis}

Table 1 presents summary statistics on inflation across cities and across sectors for the full sample period and for two sub-sample periods, using the official adoption date of IT (April 1998) as the breakpoint. The upper panel of Table 1 reports the mean inflation rate for each of the 30 cities along with the minimum and maximum rates observed across sectoral inflation series in the corresponding city. Over the whole sample period, 'Durable goods' (Item 7) and 'Oils' (Item 10) were consistently the sectors that experienced the lowest and highest inflation rates in all 30 cities. Looking across the two sub-samples, we observe a notable 
Table 1: Summary Statistics of Citywide Inflation in Korea

\begin{tabular}{|c|c|c|c|c|c|c|c|c|c|}
\hline & \multicolumn{3}{|c|}{ Full sample } & \multicolumn{3}{|c|}{ 1990:M1-1998:M3 } & \multicolumn{3}{|c|}{ 1998:M4-2014:M8 } \\
\hline & Mean & Min & $\operatorname{Max}$ & Mean & Min & Max & Mean & Min & $\operatorname{Max}$ \\
\hline \multicolumn{10}{|c|}{ By cities } \\
\hline AND & 3.67 & $-0.08(7)$ & $7.32(10)$ & 5.95 & $0.52(7)$ & $10.27(10)$ & 2.64 & $-0.35(7)$ & $6.00(10)$ \\
\hline $\mathrm{BOR}$ & 3.94 & $0.27(7)$ & $7.94(10)$ & 6.31 & $0.44(7)$ & $10.89(10)$ & 2.87 & 0.19 ( 7) & $6.61(10)$ \\
\hline $\mathrm{BCN}$ & 3.94 & $0.27(7)$ & $7.88(10)$ & 6.18 & $0.82(7)$ & $11.80(10)$ & 2.93 & $0.02(7)$ & $6.12(10)$ \\
\hline BSN & 4.02 & $0.23(7)$ & $7.53(10)$ & 6.31 & $0.10(7)$ & $10.70(10)$ & 2.99 & $0.28(7)$ & $6.15(4)$ \\
\hline CAN & 3.83 & $0.25(7)$ & $7.61(10)$ & 6.07 & $0.10(7)$ & $10.78(10)$ & 2.83 & $0.32(7)$ & $6.19(10)$ \\
\hline $\mathrm{CHE}$ & 3.72 & $0.03(7)$ & $7.86(10)$ & 5.66 & $0.06(7)$ & $11.55(10)$ & 2.85 & $0.01(7)$ & $6.20(10)$ \\
\hline $\mathrm{CCN}$ & 3.93 & $0.26(7)$ & $7.53(10)$ & 6.25 & $-0.16(7)$ & $10.47(10)$ & 2.89 & $0.45(7)$ & $6.21(10)$ \\
\hline $\mathrm{CHU}$ & 3.76 & $0.05(7)$ & $7.49(10)$ & 5.80 & $-0.32(7)$ & $10.46(10)$ & 2.85 & $0.21(7)$ & $6.16(10)$ \\
\hline DGU & 3.78 & $-0.14(7)$ & $7.51(10)$ & 6.01 & $-0.20(7)$ & $11.04(10)$ & 2.78 & $-0.11(7)$ & $5.92(10)$ \\
\hline DJN & 4.00 & $0.01(7)$ & $7.61(10)$ & 6.58 & $-0.11(7)$ & $11.34(10)$ & 2.84 & $0.07(7)$ & $5.94(10)$ \\
\hline GNG & 3.87 & $-0.06(7)$ & $8.06(10)$ & 5.88 & $-0.23(7)$ & $12.34(10)$ & 2.97 & $0.02(7)$ & $6.22(5)$ \\
\hline GUM & 3.78 & $-0.01(7)$ & 7.51 (10) & 5.82 & $-0.31(7)$ & $10.93(10)$ & 2.87 & $0.12(7)$ & $5.98(10)$ \\
\hline GSN & 3.93 & $-0.02(7)$ & 7.59 (10) & 6.12 & $-0.26(7)$ & 11.05 (10) & 2.95 & 0.09 ( 7) & $6.03(10)$ \\
\hline GWJ & 3.88 & $0.08(7)$ & 7.32 (10) & 6.03 & $-0.16(7)$ & $10.53(10)$ & 2.91 & $0.19(7)$ & $6.12(4)$ \\
\hline GNJ & 3.74 & $-0.12(7)$ & $7.61(10)$ & 5.92 & $-0.16(7)$ & $11.03(10)$ & 2.76 & $-0.10(7)$ & $6.07(10)$ \\
\hline $\mathrm{ICN}$ & 3.82 & $0.23(7)$ & $7.63(10)$ & 5.92 & $0.26(7)$ & $11.36(10)$ & 2.88 & $0.22(7)$ & $5.95(10)$ \\
\hline JJD & 3.84 & $-0.26(7)$ & $8.21(10)$ & 6.13 & $-0.40(7)$ & $12.13(10)$ & 2.81 & $-0.19(7)$ & $6.45(10)$ \\
\hline JEN & 3.97 & $-0.25(7)$ & $7.58(10)$ & 6.47 & $-0.96(7)$ & $11.03(10)$ & 2.85 & $0.06(7)$ & $6.39(4)$ \\
\hline JIN & 3.67 & $0.27(7)$ & 7.57 (10) & 5.77 & $0.82(7)$ & $11.30(10)$ & 2.73 & $0.02(7)$ & $5.90(10)$ \\
\hline MKP & 3.95 & $0.23(7)$ & $7.44(10)$ & 6.25 & $0.51(7)$ & $10.78(10)$ & 2.92 & $0.10(7)$ & $5.95(10)$ \\
\hline NWN & 3.86 & $-0.10(7)$ & 8.29 (10) & 5.79 & $-0.14(7)$ & $12.22(10)$ & 3.00 & $-0.09(7)$ & $6.53(10)$ \\
\hline $\mathrm{PHN}$ & 3.62 & $0.18(7)$ & 7.55 (10) & 5.77 & $0.26(7)$ & 11.01 (10) & 2.66 & $-0.35(12)$ & $6.00(10)$ \\
\hline SGN & 4.00 & $-0.01(7)$ & 7.88 (10) & 6.38 & $-0.20(7)$ & 11.55 (10) & 2.92 & $0.08(7)$ & $6.24(10)$ \\
\hline SEL & 3.84 & $0.01(7)$ & $8.21(10)$ & 5.68 & $-0.20(7)$ & $12.08(10)$ & 3.02 & $0.10(7)$ & $6.47(10)$ \\
\hline $\mathrm{SCN}$ & 3.86 & $0.06(7)$ & $7.58(10)$ & 5.96 & $0.21(7)$ & $10.84(10)$ & 2.92 & $0.00(7)$ & $6.93(4)$ \\
\hline SWN & 4.04 & $0.15(7)$ & $7.79(10)$ & 6.37 & $0.32(7)$ & $11.46(10)$ & 2.99 & $0.07(7)$ & $6.14(10)$ \\
\hline UJB & 3.97 & $0.08(7)$ & $7.90(10)$ & 6.08 & $0.18(7)$ & $11.62(10)$ & 3.02 & $0.03(7)$ & $6.23(10)$ \\
\hline ULS & 3.75 & $0.13(7)$ & $7.98(10)$ & 5.29 & $-0.38(7)$ & $12.35(10)$ & 3.06 & $0.35(7)$ & $6.02(10)$ \\
\hline WNJ & 3.93 & $-0.04(7)$ & $7.84(10)$ & 6.08 & $-0.22(7)$ & 11.32 (10) & 2.96 & $0.04(7)$ & $6.28(10)$ \\
\hline YSU & 3.73 & $-0.02(7)$ & $7.21(10)$ & 5.45 & $0.09(7)$ & $9.85(10)$ & 2.95 & $-0.06(7)$ & $6.02(10)$ \\
\hline \multicolumn{10}{|c|}{ By $\mathrm{CPI}$ items } \\
\hline All items & 3.85 & $3.62[\mathrm{PHN}]$ & 4.04 [SWN] & 1 & 5.29 [ULS] & 6.58 [DJN] & 2.89 & 2.64 [AND] & 3.06 [ULS] \\
\hline Commodities (1) & 3.85 & 3.69 [AND] & 4.08 [JEN] & 5.01 & 4.26 [GNG] & 5.64 [JEN] & 3.33 & 3.10 [AND] & 3.53 [SEL] \\
\hline Services (2) & 4.07 & $3.73[\mathrm{PHN}]$ & $4.42[\mathrm{SWN}]$ & 7.59 & 6.44 [ULS] & 8.38 [GNG] & 2.49 & $2.09[\mathrm{PHN}]$ & 2.79 [SWN] \\
\hline Agricultural products (3) & 4.97 & $4.46[\mathrm{YSU}]$ & $5.57[\mathrm{BCN}]$ & 7.19 & 5.67 [SEL] & $8.29[\mathrm{CHU}]$ & 3.98 & 3.13 [GNJ] & $4.79[\mathrm{GUM}]$ \\
\hline Stock products (4) & 4.60 & $3.82[\mathrm{SGN}]$ & $5.55[\mathrm{SCN}]$ & 2.60 & 0.07 [SGN] & 4.63 [UJB] & 5.49 & $4.82[\mathrm{CHU}]$ & $6.93[\mathrm{SCN}]$ \\
\hline Marine products (5) & 5.24 & $4.10[\mathrm{YSU}]$ & 7.24 [JEN] & 7.45 & 4.38 [SEL] & $9.92[\mathrm{GSN}]$ & 4.25 & $2.37[\mathrm{CNA}]$ & $6.22[\mathrm{GNG}]$ \\
\hline Processed food (6) & 4.83 & $4.52[\mathrm{PHN}]$ & 5.18 [YSU] & 6.36 & $5.58[\mathrm{PHN}]$ & $6.97[\mathrm{SCN}]$ & 4.14 & 3.75 [AND] & $4.71[\mathrm{YSU}]$ \\
\hline Durable goods (7) & 0.06 & $-0.26[\mathrm{JJD}]$ & $0.27[\mathrm{BCN}]$ & 0.01 & $-0.96[\mathrm{JEN}]$ & $0.82[\mathrm{JIN}]$ & 0.08 & $-0.35[\mathrm{AND}]$ & $0.45[\mathrm{CCN}]$ \\
\hline Textile products (8) & 2.89 & $2.51[\mathrm{WNJ}]$ & $3.34[\mathrm{BOR}]$ & 3.20 & $2.17[\mathrm{WNJ}]$ & $4.64[\mathrm{BOR}]$ & 2.74 & $2.59[\mathrm{ICN}]$ & $2.86[\mathrm{AND}]$ \\
\hline Publications (9) & 5.06 & $4.85[S W N]$ & $5.32[\mathrm{CCN}]$ & 8.13 & $7.45[S W N]$ & $8.99[\mathrm{CCN}]$ & 3.68 & 3.56 [GWJ] & $3.76[\mathrm{PHN}]$ \\
\hline Oils (10) & 7.70 & $7.21[\mathrm{YSU}]$ & $8.29[\mathrm{NWN}]$ & 11.20 & 9.85 [YSU] & 12.35 [ULS] & 6.13 & $5.88[\mathrm{GWJ}]$ & $6.61[\mathrm{BOR}]$ \\
\hline Other industrial products (11) & 3.62 & 3.34 [ULS] & $3.89[\mathrm{ICN}]$ & 4.69 & $4.08[\mathrm{YSU}]$ & 5.39 [JEN] & 3.14 & $2.89[\mathrm{JIN}]$ & $3.46[\mathrm{ICN}]$ \\
\hline Rental for housing (12) & 2.46 & $1.42[\mathrm{JIN}]$ & $3.61[\mathrm{SGN}]$ & 5.26 & $3.29[\mathrm{CHU}]$ & $8.77[\mathrm{GNJ}]$ & 1.20 & $-0.35[\mathrm{PHN}]$ & $2.57[S G N]$ \\
\hline Public services (13) & 3.93 & $3.43[\mathrm{GNJ}]$ & 4.39 [SGN] & 7.09 & $5.87[\mathrm{GNJ}]$ & 8.17 [AND] & 2.50 & 2.03 [JJD] & $2.83[S W N]$ \\
\hline Eating out (14) & 4.28 & $3.72[\mathrm{JIN}]$ & $4.77[\mathrm{CHU}]$ & 8.01 & $6.50[\mathrm{JIN}]$ & $9.36[\mathrm{BOR}]$ & 2.60 & $2.26[S G N]$ & 2.97 [ULS] \\
\hline
\end{tabular}

Notes: Entries are the annualized monthly inflation rates. Entries inside square brackets and parenthesis respectively represent cities and disaggregate CPI items.

decline in mean inflation in each city after IT adoption. More significantly, the cross-city dispersion of mean inflation significantly dropped as well. The headline average city-level inflation rate for the pre-IT sample exhibits a wide variation 
from $5.29 \%$ (ULS) to $6.58 \%(\mathrm{DJN})$, while the range narrows in the post-IT period to between $2.64 \%$ (AND) and $3.06 \%$ (ULS). This decline in the cross-city dispersion of inflation may indicate that the change in monetary policy regime has contributed to intra-national convergence of city inflation rates in Korea.

The bottom panel of the table reveals considerable variation in regional inflation for each disaggregate CPI item. It is worth noting that disaggregate inflation is higher than the headline inflation rate in the majority of sectors (in 10 out of 14 disaggregate items) and that disaggregate inflation series display a larger variation across cities compared to the aggregate counterparts. These patterns are also apparent in each of the sub-sample periods under consideration. Looking at 'Marine products' (Item 5) for example, the average inflation rate is $4.10 \%$ in Yeosu (YSU) and 7.24\% in Jeonju (JEN). More interestingly, there is a marked reduction in mean inflation after IT adoption in almost all the series considered, consistent with a beneficial impact of IT. In headline inflation ('All items'), for instance, the mean inflation rate dropped from more than $6 \%$ in the pre-IT period to below $3 \%$ in the post-IT period. The significant fall in mean inflation is also observed in all disaggregate items under study, with the exceptions of 'Stock products' (Item 4) and 'Durable goods' (Item 7). Our results indicate that the decline in mean inflation is greater for services than for commodities. Whereas mean inflation for 'Commodities' (Item 1) has declined from 5.01\% to 3.33\%, that for 'Services' (Item 2) has dropped from $7.59 \%$ to $2.49 \%$. This is in line with the recent finding by Choi and O'Sullivan (2013) that the adoption of IT in Canada exerted a stronger effect on the products whose prices are adjusted less frequently, such as services. It is also consistent with the stylized fact that less tradeable categories, such as services, are more responsive to a change in the domestic policy regime than commodities, such as 'Oils', whose price movements are largely influenced by global market developments. To view this through another lens, we look at the empirical densities of inflation series before and after IT adoption. Figure 1 displays the empirical densities of city-level inflation before (dotted line) and after (solid line) IT adoption for each sector. The plots show clearly that impacts on the distribution of city-level inflation is far from uniform across sectors. 
Figure 1: Empirical Densities of Sectoral Inflation before (dotted line) and after (solid line) IT Adoption
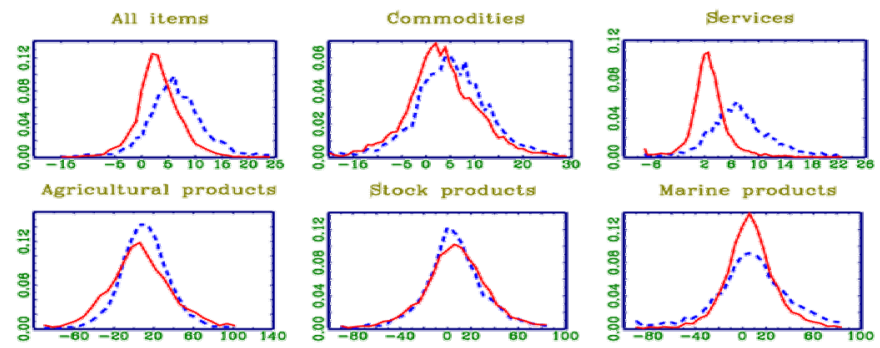

stock products

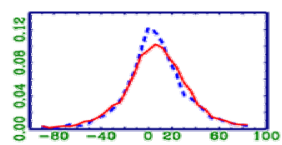

Marine proiducts
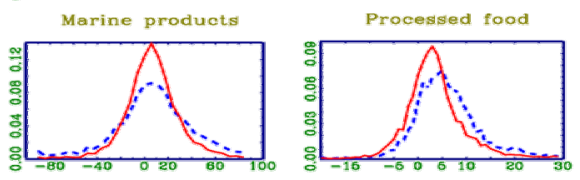

Durable goods
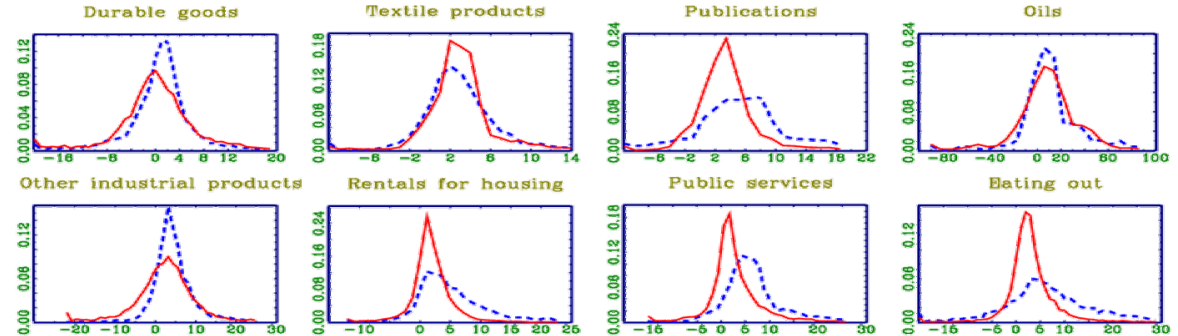

While the distributions for some sectors get slimmer and clearly shift to the left after IT adoption, indicating lower and more stable inflation, distributions for other sectors show little movement between the pre- and post-IT periods. We notice that the distribution shifts are more pronounced in service-related sectors, suggesting that the lower and more stable aggregate inflation under the IT regime may have been driven by these sectors. This result reinforces our earlier findings on the heterogeneous effect of IT adoption on the regional and sectoral inflation series.

To ensure the robustness of our findings to the choice of sample periods, we display the dynamic behavior of sectoral inflation in Korean cities in Figure 2, which plots the evolution of city-level inflation for the 30 cities (dotted line) and median inflation (solid line) over time, along with the announced target range of inflation adopted by the Bank of Korea (BOK) since April 1998.4) A couple of

4) The BOK initially set a target inflation range of $8-10 \%$ which was drastically lowered to $2-4 \%$ in 1999 and it was re-adjusted to the range of $1.5-3.5 \%$ in 2000 before going back to the range of $2-4 \%$ in 2001 . Since then, the BOK has maintained the medium-run inflation target around $3 \%$ with variable ranges between $2.0 \%$ and $4.0 \%$. 
Figure 2: 12-month City-Level Inflation Rates with Targeted Levels (red line)
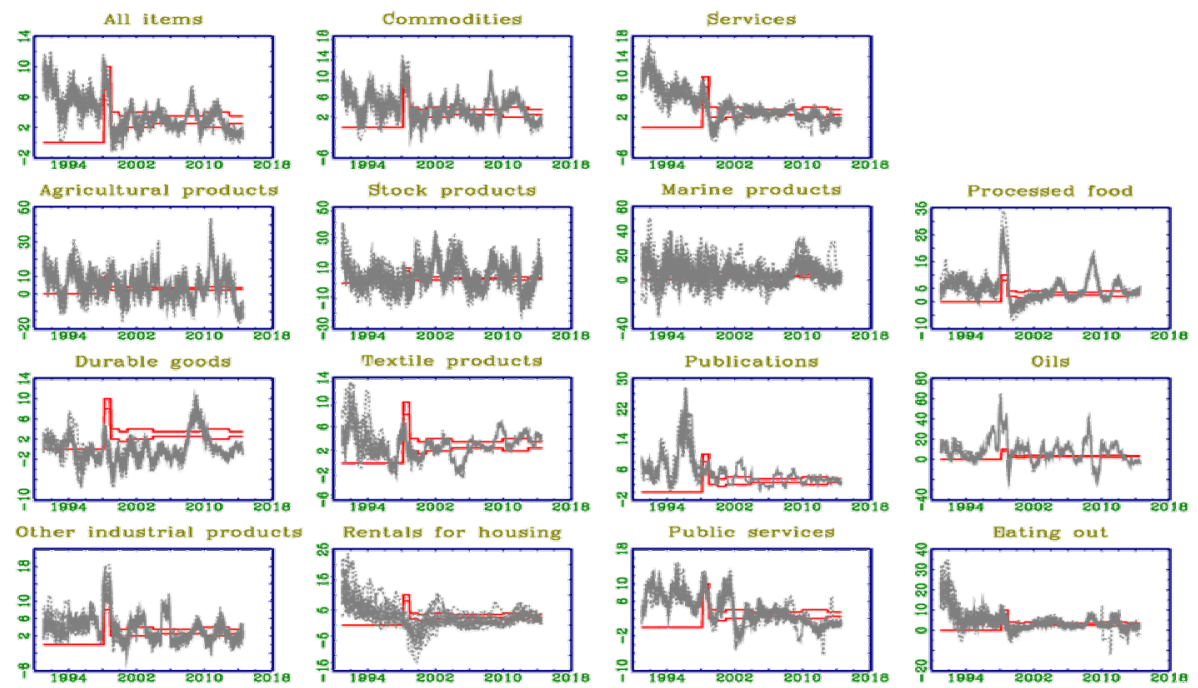

features of the plots in Figure 2 are noteworthy. First, the adoption of IT seems to have affected the dynamics of inflation differently in different sectors. Specifically, in sectors like 'Services', 'Public services' and 'Eating out', inflation quickly fell to levels near the targeted range after the adoption of IT, indicating that stabilization in overall inflation after the IT adoption may have been driven by these sectors. In contrast, such a downward adjustment towards the target range is not seen in other sectors, such as 'Commodities', 'Agricultural products', and 'Oils', where city-level inflation rates frequently deviate from the upper and lower bounds of the target range under the IT regime. Second, the plots show a high degree of co-movement across the 30 cities, especially in the headline inflation series and the highly aggregated commodities and services series. From the early 1990s onwards, headline inflation rates of all the cities appear to move together closely and hence seem to have a significant common component throughout the entire sample period. The degree of synchronization of inflation, however, appears to vary significantly across disaggregate CPI items. While city-level inflation is highly synchronized over time in 'Oils', other disaggregate CPI series such as 'Marine products' (Item 5) and 'Rentals for housing' (Item 12) exhibit much less spatial synchronization, as city-level inflation rates are widely dispersed. 
Figure 3: Cross-City Dispersion of Inflation Rates
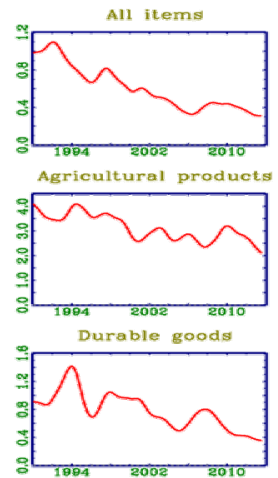

Other industrial product

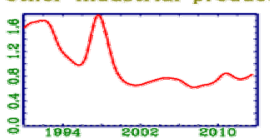

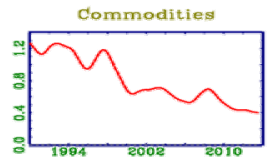
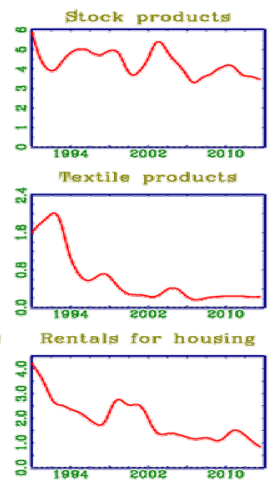
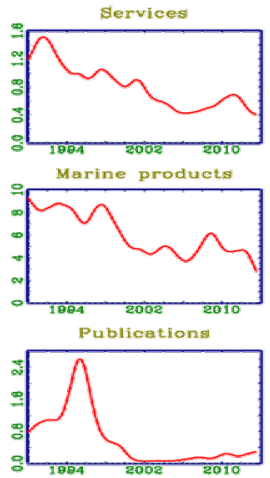

Public services

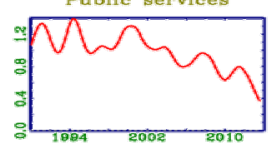

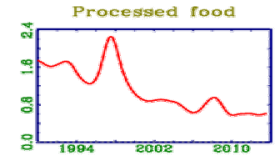

Oilst
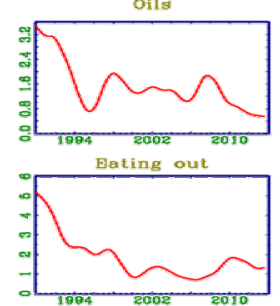

An essentially similar story is told in Figure 3, which portrays the cross-city dispersion of inflation rates measured by the cross-sectional standard deviation over the sample period. While there is considerable heterogeneity across sectors in the measure of rolling spatial correlation among cities, a peak coinciding with the mid-1990s is observable in most sectors, reflecting the time of IT adoption. As can be seen from the plots, the dispersion of aggregate inflation across cities declined substantially in the late 1990s when the BOK adopted the new monetary policy regime. The decline in cross-city dispersion is not equally apparent in all CPI sectors, however, with a marked fall observed for manufacturing sectors such as 'Processed food' and 'Textile products' but no clear shift for sectors such as 'Agricultural products' and 'Stock products'.

Overall, our results strongly suggest that the adoption of IT contributed to a reduction in headline inflation at the regional level and to a reduction in the dispersion of city-level inflation. The nature and extent of the impact of IT adoption, however, is highly heterogeneous across sectors, with a clear distinction between the service and commodity sectors. This implies that aggregate inflation may mask huge cross-city differences in regional inflation dynamics at the sectoral level. A deeper understanding of the behavior of city-level disaggregate inflation 
series, therefore, may prove useful in deciphering the channels through which the change in monetary policy regime operated. To gain further insight into this issue, we next turn to more formal econometric analysis.

\section{Econometric Analysis of City-Level Inflation by Sector}

The descriptive statistics discussed in the previous section imply that the adoption of IT has had a significant but heterogeneous impact on inflation dynamics at the regional level. Given the limited information in summary statistics, we build on our analysis by utilizing a range of more formal econometric methods: (i) structural break tests; (ii) measures of the dynamic properties of city-level inflation; (iii) common factor analysis; (vi) the degree of spatial correlation; and (v) intercity relative prices. We then investigate differences in the degree of price stickiness as a potential source of the heterogeneity observed across sectors.

\section{Structural Changes in Inflation}

We first look at whether a regime shift in monetary policy induces any structural shift in the dynamics of city-level inflation at both the aggregate and sectoral level. To the extent that a structural change in the mean of inflation reflects a shift in economic agents' perceptions of the policy target for inflation (e.g., Choi 2010, Kozicki and Tinsley 2001), one may expect to see evidence of structural changes in the city-level sectoral series around the time of IT adoption. The summary statistics presented in the previous section convincingly suggest a heterogeneous response across sectors to IT adoption and so it is of interest to see whether a structural break is present in some sectors but not in others. To this end, we utilize a battery of the popular multiple structural break tests developed by Bai and Perron (1998) in which break points were identified by applying the sequential multiple breakpoint test to the 30 city-level inflation series in each CPI sector under study. Specifically, we consider the following two structural change 
models to identify a structural break in either the level or persistence of the city-level inflation series. For the level of inflation, we use a pure structural change model,

$$
\pi_{t}=\delta^{(j)}+\varepsilon_{t}
$$

where the breaks are assumed to be in the mean of inflation $\left(\delta^{(j)}\right)$. For the persistence of inflation we employ a partial structural change model of

$$
\pi_{t}=x_{t}^{\prime} \beta+z_{t}^{\prime} \delta_{j}+u_{t}
$$

with $x_{t}=\left\{\pi_{t-2}, \ldots, \pi_{t-p}\right\}$ and $z_{t}=\left\{\mathrm{c}, \pi_{t-1}\right\}$ such that the coefficient for inflation is allowed to shift.5)

Figure 4 displays the frequency of estimated structural break points in the inflation series of the 30 cities for aggregate CPI.6) As can be seen from Figure 4, the timing of the break points in mean inflation is very similar across sectors and two dominant break points emerge: the first occurs around 1998, which coincides with the official adoption date of IT, and the second around 2001, which may represent the onset of an expansionary monetary policy stance by the BOK (e.g., Kim and Park 2006). When it comes to the persistence of the inflation series, however, the outcome of the break tests is not so straightforward to interpret. In aggregate inflation, several break points are found, with a dominant one around 1998 when the BOK launched the new monetary policy regime. In addition, some more minor break points are identified in the post-IT period, around 2003, 2007 and 2010. For the disaggregate CPI series, the timing of break points is quite heterogeneous across sectors. The timing of a dominant break point coincides with the official adoption of IT in some sectors such as services, but not in others,

5) The lag length $(p)$ is selected by the AIC rule. Following the guidelines from Bai and Perron, the break is assumed not to occur during the initial $15 \%$ nor the final $15 \%$ of the sample period in testing for structural breaks. The maximum number of breaks is set to five and the minimum regime size is set to $5 \%$ of the sample. Robust standard errors are based on a quadratic spectral kernel HAC estimator with AR(1) prewhitening filters.

6) Structural break points for 14 disaggregate CPI series are also available upon request. 
Figure 4: Frequency of Estimated Break Points for Mean Inflation (first column) and Inflation Persistence (second column)
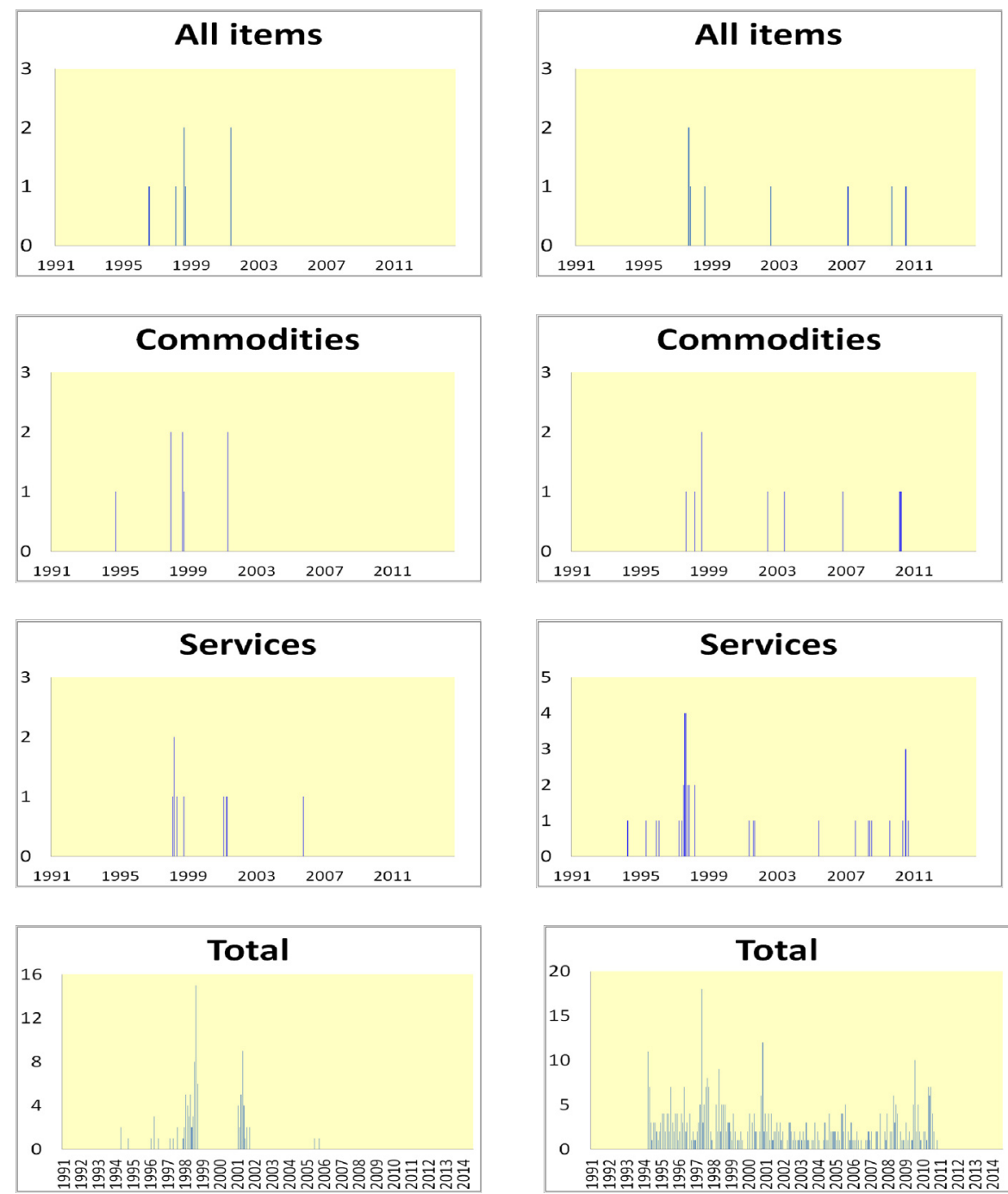

in support of our prior argument. Moreover, in almost all the disaggregate CPI items, a number of break points emerge before and after the onset of the IT adoption, but their timing did not coincide across sectors. This is indicative of substantial heterogeneity of regional inflation dynamics across sectors even under the IT regime. 


\section{Dynamic Properties of Inflation Series}

In the literature, an enormous effort has been devoted to the analysis of the dynamic properties of inflation, with particular emphasis being placed on volatility and persistence. Not surprisingly, the success of inflation targeting as a monetary policy framework is often assessed based on its impact on these dynamics.7) Benati (2008), for example, studied a number of industrialized countries and found a notable fall in inflation persistence in all the countries that have adopted IT. Since inflation persistence is known to reflect the formation of inflation expectations, such a decline in persistence under an IT regime is often attributed to a quick transition of inflation expectations formation from backwardlooking indexation to a forward-looking mechanism after the establishment of a clearly defined nominal anchor (e.g., Erceg and Levin 2003, Orphanides and Williams 2005). While much of the existing research is concerned with the persistence of aggregate inflation, a growing literature at the disaggregate level, including Bilke (2005) and Altissimo et al. (2009), uncovers the presence of widely different degrees of inflation inertia across sectors, with sectoral rates generally exhibiting a much lower degree of inertia than their aggregate counterpart. Moreover, there is also some evidence that a change in monetary regime can impact regional differences in inflation persistence (e.g., Meller and Nautz 2009, Tillmann 2013).

In this section, we evaluate the extent to which IT exerts a measurable influence on inflation volatility and persistence in Korean cities. We first measure the temporal volatility of each city-level inflation series using its standard deviation. The upper panel of Table 2 reports summary statistics for inflation volatility averaged across cities before and after IT adoption. For aggregate inflation, the adoption of IT is clearly associated with a marked reduction in volatility as the range of standard deviations across cities narrowed noticeably. The fall in volatility was not uniform across all sectors, and indeed some sectors,

7) See, for example, Mishkin and Schmidt-Hebbel (2007) on the reduction of inflation volatility in countries that adopted IT and Altissimo et al. (2006), Benati (2008) and Levin and Piger (2004) on the impact of monetary policy regime change on the persistence of the inflation process. 
Table 2: Volatility and Persistence of City Inflation by CPI Items

\begin{tabular}{|c|c|c|c|c|c|c|c|c|c|c|c|c|c|}
\hline & \multicolumn{4}{|c|}{ Full sample } & \multicolumn{4}{|c|}{ Pre-IT period } & \multicolumn{4}{|c|}{ Post IT-period } & \multirow{3}{*}{ 주 } \\
\hline & \multicolumn{2}{|c|}{ 12-month } & \multicolumn{2}{|c|}{ Month-to-month } & \multicolumn{2}{|c|}{ 12-month } & \multicolumn{2}{|c|}{ Month-to-month } & \multicolumn{2}{|c|}{ 12-month } & \multicolumn{2}{|c|}{ Month-to-month } & \\
\hline & ALL & $(\min , \max )$ & ALL & $(\min , \max )$ & ALL & $(\min , \max )$ & ALL & $(\min , \max )$ & ALL & $(\min , \max )$ & ALL & $(\min , \max )$ & \\
\hline \multicolumn{13}{|c|}{ Volatility } & D \\
\hline All items & 2.1 & $(2.0,2.6)$ & 4.1 & $(4.0,5.6)$ & 1.8 & $(1.5,2.9)$ & 4.7 & $(4.7,7.3)$ & 1.4 & $(1.3,2.0)$ & 3.3 & $(3.0,4.4)$ & อ \\
\hline Commodities & 2.3 & $(2.1,3.0)$ & 7.0 & $(6.9,8.8)$ & 2.3 & $(1.7,3.5)$ & 7.6 & $(7.6,11.0)$ & 2.2 & $(2.1,2.8)$ & 6.5 & $(6.3,8.0)$ & 2 \\
\hline Services & 2.8 & $(2.5,3.5)$ & 3.7 & $(3.7,5.7)$ & 2.2 & $(1.5,3.5)$ & 4.0 & $(3.6,7.1)$ & 1.3 & $(1.2,1.8)$ & 2.1 & $(2.1,4.4)$ & 0 \\
\hline Agricultural products & 7.6 & $(7.4,9.1)$ & 28.0 & $(28.0,36.3)$ & 6.5 & $(5.7,9.6)$ & 19.3 & $(19.3,31.7)$ & 7.9 & $(7.7,9.6)$ & 31.5 & $(31.3,40.3)$ & \\
\hline Stock products & 7.0 & $(6.8,9.3)$ & 20.9 & $(20.9,38.2)$ & 4.7 & $(4.2,9.6)$ & 18.8 & $(18.8,37.3)$ & 7.6 & $(6.8,10.3)$ & 22.0 & $(22.0,38.7)$ & 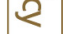 \\
\hline Marine products & 5.1 & $(5.1,10.9)$ & 14.7 & $(14.7,40.8)$ & 6.8 & $(6.6,14.9)$ & 18.1 & $(18.1,57.0)$ & 4.1 & $(4.1,9.8)$ & 12.6 & $(12.6,32.4)$ & 叉 \\
\hline Processed food & 4.2 & $(4.1,6.1)$ & 7.1 & $(7.1,10.6)$ & 3.1 & $(2.9,4.8)$ & 9.2 & $(9.1,15.2)$ & 4.5 & $(4.4,6.6)$ & 5.3 & $(5.3,7.5)$ & (1) \\
\hline Durable goods & 2.5 & $(2.3,2.9)$ & 6.2 & $(6.0,7.4)$ & 1.8 & $(1.5,3.3)$ & 4.9 & $(4.1,7.2)$ & 2.8 & $(2.4,3.1)$ & 6.8 & $(6.3,8.2)$ & $\underline{z}$. \\
\hline Textile products & 1.9 & $(1.7,2.8)$ & 4.7 & $(4.6,5.9)$ & 2.4 & $(1.8,4.1)$ & 6.0 & $(5.5,8.6)$ & 1.6 & $(1.6,1.8)$ & 3.9 & ( $3.7,4.6)$ & D \\
\hline Publications & 3.6 & $(3.2,4.3)$ & 8.6 & $(8.3,10.8)$ & 4.6 & $(3.4,6.1)$ & 11.3 & $(10.7,16.1)$ & 1.7 & $(1.5,1.8)$ & 6.3 & $(6.2,6.5)$ & \\
\hline Oils & 11.2 & $(10.7,12.2)$ & 37.7 & $(35.7,41.2)$ & 11.9 & $(11.3,13.0)$ & 52.9 & $(49.4,57.8)$ & 10.5 & $(9.9,11.5)$ & 26.8 & $(25.0,30.1)$ & \\
\hline Other industrial products & 2.9 & $(2.6,3.7)$ & 9.2 & $(9.2,11.2)$ & 1.9 & $(1.8,3.1)$ & 7.5 & $(7.1,10.9)$ & 3.1 & $(2.6,3.9)$ & 9.8 & $(9.5,11.6)$ & \\
\hline Rental for housing & 3.1 & $(2.2,5.1)$ & 3.7 & $(3.7,11.9)$ & 3.0 & $(1.9,7.2)$ & 4.2 & $(4.2,19.5)$ & 2.4 & $(1.1,3.8)$ & 2.6 & $(2.4,6.6)$ & 6 \\
\hline Public services & 3.3 & $(2.9,4.0)$ & 6.2 & $(6.2,9.0)$ & 2.0 & $(1.7,2.9)$ & 6.8 & $(6.7,10.2)$ & 2.8 & $(2.4,3.3)$ & 5.3 & $(5.0,9.0)$ & $\bar{D}$ \\
\hline Eating out & 4.1 & ( $3.5,6.4)$ & 5.7 & $(5.7,17.0)$ & 5.2 & $(4.3,9.8)$ & 7.7 & $(7.7,21.8)$ & 1.6 & $(1.6,3.0)$ & 2.7 & $(2.7,16.2)$ & ע \\
\hline \multicolumn{13}{|c|}{ Persistence } & \\
\hline All items & 0.925 & $(0.894,0.948)$ & 0.620 & $(0.235,0.631)$ & 0.913 & $(0.837,0.933)$ & 0.625 & $(-0.087,0.628)$ & 0.828 & $(0.772,0.898)$ & 0.071 & $(-0.098,0.245)$ & D \\
\hline Commodities & 0.853 & $(0.814,0.904)$ & 0.281 & $(0.020,0.333)$ & 0.900 & $(0.740,0.937)$ & 0.206 & $(-0.331,0.529)$ & 0.859 & $(0.790,0.887)$ & -0.027 & $(-0.442,0.130)$ & \\
\hline Services & 0.977 & $(0.934,0.981)$ & 0.858 & $(0.608,0.858)$ & 0.955 & $(0.864,0.977)$ & 0.680 & $(-0.275,0.752)$ & 0.925 & $(0.815,0.927)$ & 0.570 & $(-0.134,0.695)$ & \\
\hline Agricultural products & 0.823 & $(0.756,0.867)$ & -0.029 & $(-0.346,0.060)$ & 0.866 & $(0.749,0.890)$ & 0.031 & $(-0.425,0.295)$ & 0.835 & $(0.785,0.883)$ & -0.303 & $(-0.539,-0.022)$ & $\bar{\alpha}$ \\
\hline Stock products & 0.880 & $(0.781,0.896)$ & 0.097 & $(-0.490,0.182)$ & 0.771 & $(0.670,0.871)$ & -0.253 & $(-0.671,0.191)$ & 0.862 & $(0.802,0.916)$ & 0.107 & $(-0.563,0.169)$ & \\
\hline Marine products & 0.840 & $(0.690,0.911)$ & 0.070 & $(-0.587,0.215)$ & 0.833 & $(0.684,0.919)$ & 0.288 & $(-0.589,0.288)$ & 0.930 & $(0.721,0.933)$ & 0.052 & $(-0.961,0.360)$ & \\
\hline Processed food & 0.950 & $(0.896,0.954)$ & 0.566 & $(0.380,0.586)$ & 0.964 & $(0.704,1.036)$ & 0.452 & $(0.252,1.014)$ & 0.941 & $(0.877,0.941)$ & 0.708 & $(0.495,0.744)$ & $\overline{\underline{Q}}$ \\
\hline Durable goods & 0.932 & $(0.903,0.947)$ & 0.406 & $(0.033,0.422)$ & 0.926 & $(0.803,0.938)$ & 0.267 & $(-0.052,0.493)$ & 0.945 & $(0.923,0.952)$ & 0.329 & $(0.127,0.480)$ & \\
\hline Textile products & 0.930 & $(0.901,0.960)$ & 0.355 & $(0.023,0.547)$ & 0.947 & $(0.858,0.966)$ & 0.354 & $(-0.245,0.440)$ & 0.923 & $(0.910,0.948)$ & 0.512 & $(0.072,0.561)$ & \\
\hline Publications & 0.919 & $(0.887,0.946)$ & 0.393 & $(0.048,0.524)$ & 0.931 & $(0.822,0.935)$ & 0.358 & $(-0.067,0.552)$ & 0.805 & $(0.800,0.815)$ & -0.133 & $(-0.195,-0.086)$ & \\
\hline Oils & 0.835 & $(0.819,0.846)$ & -0.006 & $(-0.193,0.093)$ & 0.938 & $(0.907,1.001)$ & -0.096 & $(-0.127,0.113)$ & 0.809 & $(0.753,0.825)$ & 0.258 & $(0.177,0.300)$ & \\
\hline Other industrial products & 0.899 & $(0.812,0.912)$ & -0.047 & $(-0.273,0.145)$ & 0.837 & $(0.731,0.927)$ & 0.436 & $(-0.150,0.572)$ & 0.882 & $(0.774,0.887)$ & -0.288 & $(-0.525,-0.216)$ & \\
\hline Rental for housing & 0.987 & $(0.928,0.987)$ & 0.906 & $(0.340,0.906)$ & 0.969 & $(0.774,0.984)$ & 0.738 & $(-0.543,0.890)$ & 0.979 & $(0.872,0.979)$ & 0.871 & $(-0.076,0.871)$ & \\
\hline Public services & 0.949 & $(0.926,0.967)$ & 0.657 & $(0.389,0.657)$ & 0.864 & $(0.801,0.908)$ & 0.117 & $(-0.356,0.272)$ & 0.925 & $(0.877,0.931)$ & 0.487 & $(0.096,0.489)$ & ㄱ. \\
\hline Eating out & 0.971 & $(0.835,0.971)$ & 0.816 & $(0.120,0.816)$ & 0.956 & $(0.848,0.956)$ & 0.759 & $(-0.196,0.765)$ & 0.952 & $(0.814,0.952)$ & 0.571 & $(-0.734,0.586)$ & \\
\hline
\end{tabular}


Figure 5: Volatility (S.D.) of Monthly Inflation Rates with the Median (solid line), 25 and 75 Percentiles (dotted lines) of 30 Cities
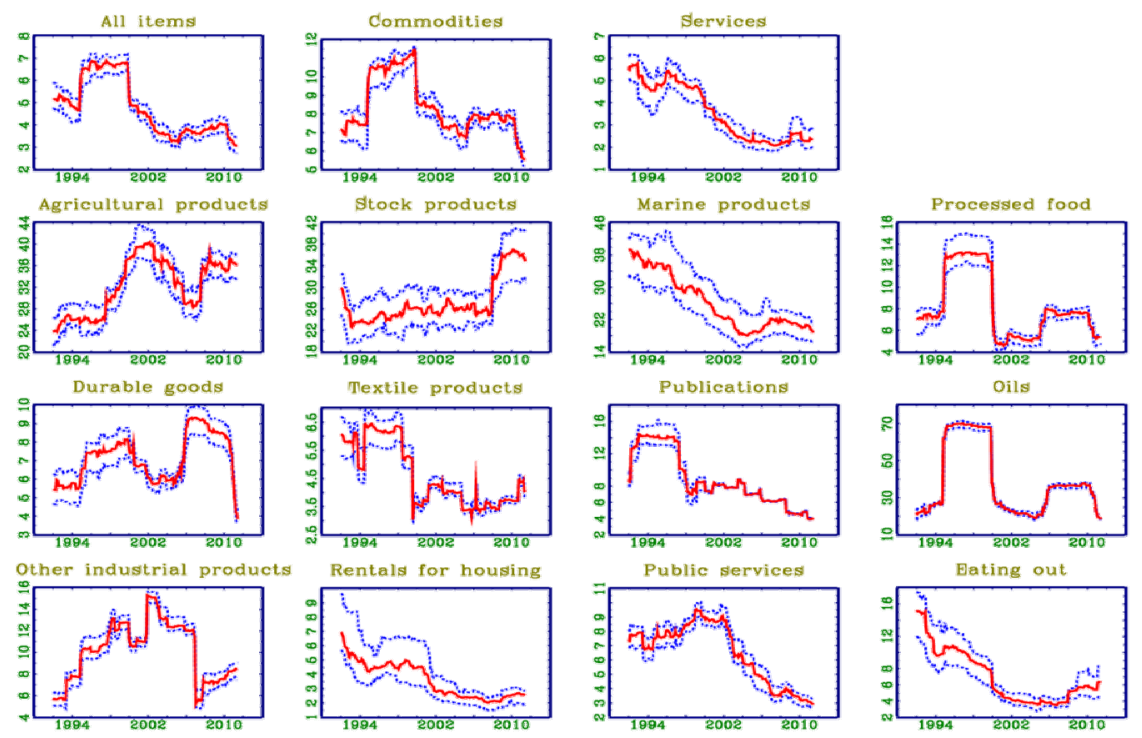

such as 'Durable goods' and 'Agricultural products', even experienced an increase in volatility after IT adoption. This may have reflected the relative importance of sector-specific shocks in those series. Looking at the binary breakdown between 'Commodities' and 'Services', it is clear that the stabilization of aggregate inflation was driven by the 'Services' category. The plots in Figure 5 present additional evidence on the impact of IT adoption on the volatility of city-level inflation across sectors. Figure 5 shows five-year rolling standard deviations of the monthly inflation rate for the 30 cities, computed using a centered 61-month window, with the median, 25\%, and $75 \%$ percentiles. Again, there is a notable decline and substantial cross-city co-movement in the volatility of aggregate inflation. The standard deviation plot clearly shows a sharp, almost discrete decline in city level inflation volatility around 1998, coinciding well with the official adoption date of IT. At the disaggregate level, however, the pattern varies substantially across sectors, with volatility in some sectors (e.g., 'Agricultural products' and 'Stock products') actually increasing over time. This supports our prior argument on the sectoral heterogeneity in the effect of IT. Focusing on the regional dimension, the 
Table 3: Change in Inflation Dynamics by Cities

\begin{tabular}{|c|c|c|c|c|c|c|c|c|c|c|c|c|}
\hline \multirow{3}{*}{ Cities } & \multicolumn{6}{|c|}{ Volatility (monthly inflation) } & \multicolumn{6}{|c|}{ Persistence (12-month inflation) } \\
\hline & \multicolumn{2}{|c|}{ All items } & \multicolumn{2}{|c|}{ Commodities } & \multicolumn{2}{|c|}{ Services } & \multicolumn{2}{|c|}{ All items } & \multicolumn{2}{|c|}{ Commodities } & \multicolumn{2}{|c|}{ Services } \\
\hline & Pre & Post & Pre & Post & Pre & Post & Pre & Post & Pre & Post & Pre & Post \\
\hline ALL & 4.69 & 3.30 & 7.65 & 6.52 & 4.04 & 2.07 & 0.913 & 0.828 & 0.900 & 0.859 & 0.955 & 0.925 \\
\hline AND & 4.79 & 3.03 & 7.84 & 6.30 & 5.05 & 2.42 & 0.887 & 0.851 & 0.877 & 0.887 & 0.956 & 0.866 \\
\hline BOR & 5.67 & 3.60 & 8.89 & 6.82 & 4.86 & 2.29 & 0.899 & 0.831 & 0.792 & 0.829 & 0.919 & 0.912 \\
\hline $\mathrm{BCN}$ & 5.40 & 3.44 & 8.69 & 6.88 & 4.32 & 2.26 & 0.919 & 0.801 & 0.804 & 0.840 & 0.957 & 0.913 \\
\hline BSN & 5.07 & 3.72 & 7.76 & 7.17 & 4.94 & 2.80 & 0.890 & 0.814 & 0.908 & 0.844 & 0.962 & 0.868 \\
\hline CNA & 5.14 & 3.42 & 8.86 & 6.89 & 4.38 & 2.57 & 0.845 & 0.867 & 0.768 & 0.867 & 0.940 & 0.927 \\
\hline CHE & 6.12 & 3.90 & 10.12 & 7.43 & 4.50 & 2.70 & 0.878 & 0.840 & 0.864 & 0.855 & 0.954 & 0.860 \\
\hline $\mathrm{CCN}$ & 5.61 & 3.85 & 7.85 & 7.19 & 6.00 & 2.77 & 0.871 & 0.888 & 0.845 & 0.877 & 0.931 & 0.874 \\
\hline $\mathrm{CHU}$ & 5.03 & 3.58 & 8.14 & 6.96 & 3.56 & 2.79 & 0.880 & 0.814 & 0.852 & 0.847 & 0.924 & 0.910 \\
\hline DGU & 5.85 & 4.09 & 9.85 & 6.74 & 5.36 & 4.43 & 0.882 & 0.813 & 0.827 & 0.859 & 0.964 & 0.880 \\
\hline DJN & 5.50 & 3.71 & 7.98 & 7.72 & 5.78 & 2.65 & 0.860 & 0.844 & 0.834 & 0.857 & 0.977 & 0.911 \\
\hline GNG & 5.93 & 3.59 & 9.46 & 7.18 & 5.19 & 2.96 & 0.912 & 0.841 & 0.870 & 0.880 & 0.945 & 0.903 \\
\hline GUM & 5.83 & 3.88 & 9.23 & 7.27 & 5.08 & 2.89 & 0.881 & 0.811 & 0.853 & 0.850 & 0.910 & 0.853 \\
\hline GSN & 6.46 & 3.88 & 9.74 & 6.93 & 5.15 & 3.29 & 0.841 & 0.807 & 0.786 & 0.848 & 0.925 & 0.897 \\
\hline GWJ & 6.68 & 4.44 & 9.87 & 7.73 & 6.94 & 3.71 & 0.876 & 0.832 & 0.848 & 0.863 & 0.945 & 0.906 \\
\hline GNJ & 5.57 & 3.83 & 8.90 & 6.98 & 4.03 & 2.73 & 0.853 & 0.848 & 0.817 & 0.840 & 0.935 & 0.903 \\
\hline $\mathrm{ICN}$ & 6.45 & 4.18 & 10.10 & 7.64 & 5.05 & 2.74 & 0.893 & 0.822 & 0.798 & 0.848 & 0.941 & 0.914 \\
\hline JJD & 7.25 & 4.12 & 10.98 & 7.29 & 5.82 & 3.20 & 0.915 & 0.834 & 0.887 & 0.879 & 0.952 & 0.847 \\
\hline JEN & 6.30 & 4.29 & 9.88 & 7.47 & 5.61 & 2.96 & 0.889 & 0.895 & 0.850 & 0.826 & 0.923 & 0.893 \\
\hline$J \mathbb{N}$ & 5.51 & 4.10 & 9.02 & 7.31 & 4.19 & 3.42 & 0.933 & 0.779 & 0.925 & 0.790 & 0.944 & 0.887 \\
\hline MKP & 6.05 & 4.44 & 9.19 & 7.88 & 5.46 & 3.54 & 0.853 & 0.865 & 0.868 & 0.863 & 0.935 & 0.864 \\
\hline NWN & 6.52 & 4.19 & 9.42 & 7.71 & 6.84 & 3.69 & 0.849 & 0.823 & 0.740 & 0.874 & 0.952 & 0.869 \\
\hline PHN & 6.30 & 4.14 & 9.34 & 7.72 & 5.84 & 2.99 & 0.875 & 0.820 & 0.886 & 0.843 & 0.864 & 0.852 \\
\hline SGN & 6.11 & 4.05 & 9.73 & 7.61 & 5.56 & 3.22 & 0.837 & 0.839 & 0.856 & 0.839 & 0.947 & 0.898 \\
\hline SEL & 6.33 & 4.02 & 9.32 & 7.69 & 5.58 & 2.89 & 0.932 & 0.835 & 0.937 & 0.866 & 0.932 & 0.918 \\
\hline SCN & 5.89 & 4.07 & 9.38 & 7.51 & 5.25 & 2.98 & 0.899 & 0.772 & 0.851 & 0.834 & 0.943 & 0.872 \\
\hline SWN & 6.17 & 4.38 & 8.92 & 7.97 & 6.21 & 3.28 & 0.864 & 0.898 & 0.848 & 0.846 & 0.964 & 0.907 \\
\hline UJB & 5.83 & 4.38 & 8.23 & 7.59 & 5.75 & 3.24 & 0.864 & 0.844 & 0.822 & 0.841 & 0.939 & 0.900 \\
\hline ULS & 6.27 & 4.40 & 8.73 & 8.05 & 7.15 & 2.71 & 0.925 & 0.885 & 0.889 & 0.834 & 0.941 & 0.860 \\
\hline WNJ & 7.03 & 4.07 & 10.15 & 7.59 & 5.76 & 2.74 & 0.847 & 0.832 & 0.822 & 0.873 & 0.923 & 0.906 \\
\hline YSU & 5.21 & 3.68 & 8.06 & 7.27 & 6.15 & 2.72 & 0.863 & 0.808 & 0.813 & 0.862 & 0.947 & 0.815 \\
\hline
\end{tabular}

Note: 'Pre' and 'post' respectively denote the pre-IT period spanning 1990:M1-1998:M3 and the post-IT period of 1998:M4-2014:M8.

left-hand panel of Table 3 shows that the volatility of aggregate inflation has decreased substantially after IT adoption in each of the 30 cities. Consistent with the evidence in Table 2 and Figure 5, the variance reduction is particularly noticeable in 'Services' where, for example, the standard deviation of monthly inflation dropped in Ulsan (ULS) from 7.15 to 2.71 after IT adoption. Comparing the pre- and post-IT periods for each of the cities, we see that the volatility of monthly inflation for both 'Commodities' and 'Services' has fallen in every city. The decline was much more pronounced for 'Services', however, indicating that the decline in the variance of aggregate inflation is largely attributable to reduced volatility in the 'Service' sector. 
For inflation persistence, we use the reduced-form (intrinsic) persistence of each city-level inflation series measured by the of sum of autoregressive coefficients (SARC) in the $\operatorname{AR}(p)$ representation,

$$
\pi_{t}=\beta_{0}+\sum_{j=1}^{p} \beta_{j} \pi_{t-j}+\varepsilon_{t}=\alpha+\rho \pi_{t-1}+\sum_{k=1}^{p-1} \zeta_{k} \Delta \pi_{t-k}+\varepsilon_{t}
$$

where $\rho=\sum_{j=1}^{p} \beta_{j}$ denotes the SARC and the lag length $(p)$ is selected by using the BIC rule. To deal with the well-known downward small sample bias embedded in the OLS estimation of $\rho$, we follow the common practice in previous studies (e.g. Benati 2008, Clark 2006) and employ the Hansen's (1999) 'grid bootstrap' based median-unbiased (MUB) estimator. The lower panel of Table 2 presents the MUB estimates of $\rho$ in eq.(1) by sector for both the full sample and the two subsample periods. Table 2 shows that the overall inflation rate becomes significantly less persistent after the adoption of IT, in line with conventional wisdom. Not surprisingly, inflation persistence varies substantially across sectors. While the MUB estimate for the monthly inflation in 'Rental for housing' is as high as 0.91 in the full sample, it lies below zero in some sectors like 'Agricultural products', 'Oils', and 'Other industrial products', indicating that inflation in these sectors is almost indistinguishable from a white noise process. The low inflation persistence observed in those commodities sectors may not only reflect the characteristics of commodity markets in which prices are determined by ever-changing global market conditions, but also indicate the lesser scope for national monetary policy decisions to influence price dynamics in these sectors. Furthermore, in each CPI sector, there appears to be considerable variation in the persistence of the inflation series across the 30 cities. In the 'Eating out' sector, for instance, the MUB estimate exhibits a wide range of between 0.12 (half-life of 0.3 months) and 0.82 (half-life of 3.4 months).

More importantly, inflation persistence exhibits a significant fall after the adoption of IT. The fall in the MUB estimate is particularly noticeable for aggregate inflation, dropping drastically from 0.63 to 0.07 in the monthly inflation, supporting the popular view that anchoring inflation to an explicit 
Figure 6: Average Persistence of City-Level Inflation with 14 Year Rolling Window
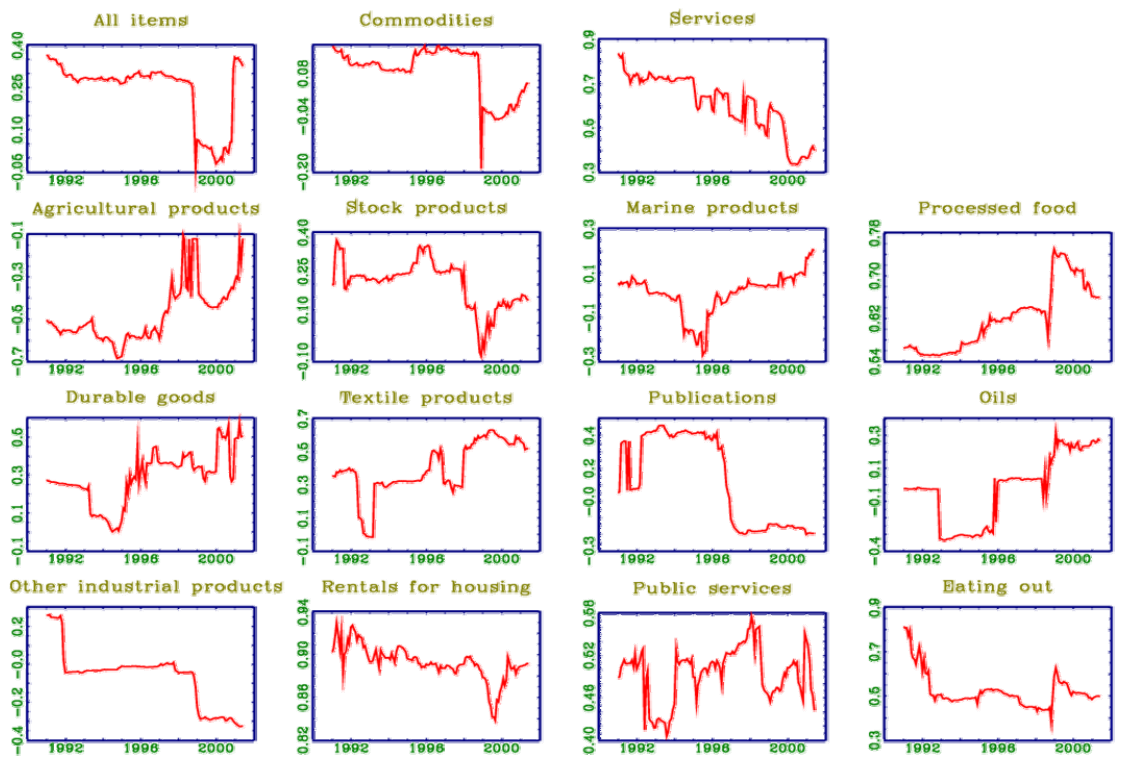

objective induces less persistence in the inflation process. This implies that IT was successful in Korea at anchoring expectations by dampening the impact of shocks that might otherwise have initiated a persistent departure of inflation from the target value. At the disaggregate level, however, the change in inflation persistence after IT adoption differs considerably across sectors. The MUB estimates of city-level inflation increased in some sectors (e.g., 'Stock products', 'Durable goods', 'Public services') under the IT regime. Figure 6 provides further evidence of sectoral heterogeneity in the persistence of inflation by displaying the persistence of monthly all-cities inflation for a rolling window of 14 years. Note that in some sectors, including aggregate inflation, persistence fell sharply in the late 1990s when IT was adopted. For other sectors, however, no such a notable decline is witnessed, with persistence either remaining stable or increasing after IT adoption, suggesting that the benefit of better-anchored expectations is not equally enjoyed by all sectors. To gain further insight on this issue at the city level, we present in the right-panel of Table 3 persistence estimates for aggregate inflation and the commodity/services breakdown by city. The MUB estimates of 
12-month aggregate inflation drop after IT adoption in the majority of cities (24 out of 30 cities). At the sectoral level, however, the picture somewhat changes. Whereas every city has a lower inflation persistence in 'Services' under the IT regime, the persistence in 'Commodities' has decreased in less than half of the cities.

Overall, our results in this section confirm the findings of previous studies (e.g., Tillmann 2013) that IT adoption lowers volatility and persistence of aggregate inflation in Korea. At a disaggregate level, however, the impact is far from uniform. The heterogeneity is far more pronounced across sectors than across regions, with changes in the dynamics of the 'Services' sector inflation dominating the impact of IT adoption on aggregate inflation across the cities.

\section{Impact of IT on Spatial Co-Movements of Inflation}

We also explore whether and how a change in monetary policy regime affect the strength of co-movements among regional inflation rates. If IT reduces uncertainty about future price developments and anchors regional inflationary expectations towards a common targeted level, one may expect the degree of co-movement of regional inflation to increase under IT. Notwithstanding the abundance of research on IT, little attention has been paid to the effect of IT on the co-movement of regional inflation, especially at the sectoral level. As a notable exception, Tillmann (2013) studies the impact of IT adoption along the regional dimension in Korea. However, he focuses on the persistence of aggregate measures of regional inflation only and does not consider sector-specific data. Using aggregate price data for 23 Korean cities and 9 provinces, the author concludes that the adoption of IT in Korea led to a much more homogeneous inflation process across regions as measured by the cross-regional standard deviation of persistence. In view of the non-negligible cross-sector heterogeneity observed, it would be informative to examine in more detail how the monetary policy regime change affects spatial co-movements of inflation at the sectoral level.

For this purpose, we first look at the co-movements of city-level inflation series using the following modified Moran's I statistic (e.g., Stock and Watson 2010), 
Figure 7: Spatial Correlation of Monthly Inflation Rates of 30 Cities (3-Year Rolling Average)
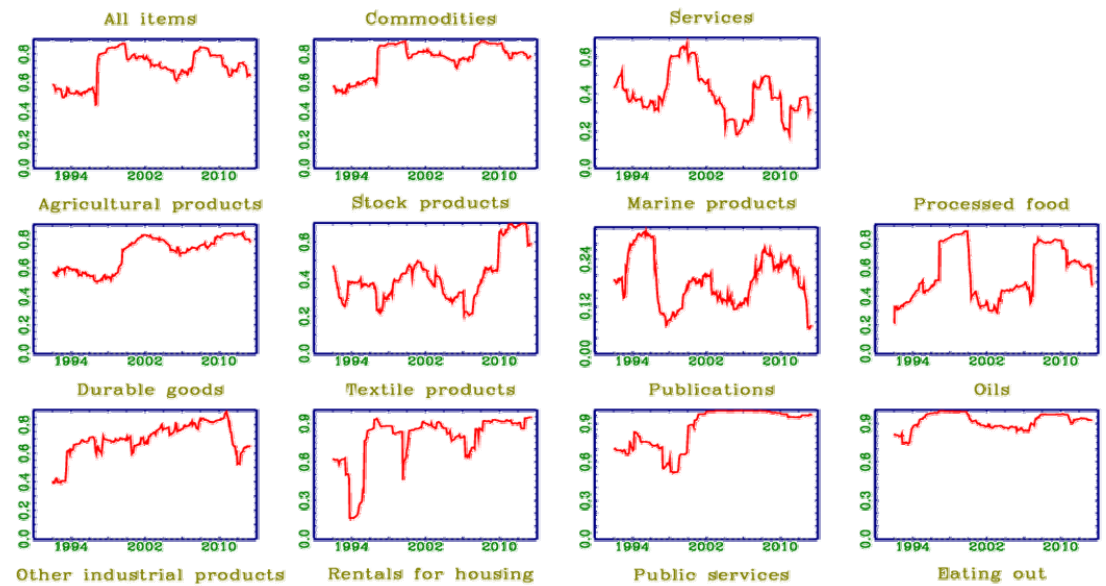

Other industrial products
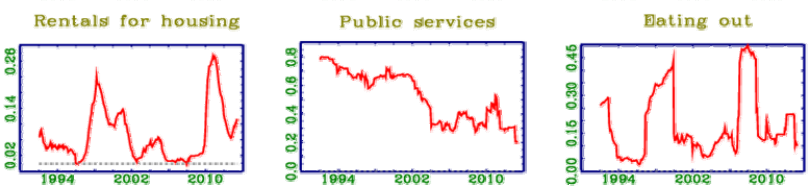

$$
\tilde{I}_{t}=\frac{\sum_{i=1}^{N} \sum_{j=1}^{i-1} \operatorname{cov}\left(\pi_{i t}, \pi_{j t}\right) \cdot 2 N}{\sum_{i=1}^{N} \operatorname{var}\left(\pi_{i t}\right) \cdot N(N-1)}, \quad N=30,
$$

where $\pi_{h t}$ denotes city $h$ 's inflation rate at $t$. Figure 7 plots the evolution of the modified Moran's I $\left(\tilde{L}_{t}\right)$ over time for both aggregate and disaggregate inflation series. In each panel, the line represents $\tilde{I}_{t}$ in eq.(2) using a centered 37-month window. The numbers on the horizontal axis therefore represent the middle point of each 3-year window. For instance, 1994 captures the subsample period of 1993-5, and so on. As shown in the first panel of Figure 7, the spatial correlation of aggregte city-level inflation rises sharply around the adoption of IT, jumping from 0.5 to 0.8 . This is consistent with the finding by Tillmann (2013) that the aggregate inflation process has become more homogeneous across regions after IT adoption. Again, there exists nontrivial heterogeneity across sectors when it comes 
to disaggregate inflation. A similar rise in Moran's I is witnessed in 'Commodities', with an increase apparent within that category in 'Agricultural products', for example. In 'Oils', the spatial correlation of city inflation remains as high as 0.9 , irrespective of the change in monetary policy regime. In contrast, after an initial increase around the time of IT adoption, 'Services' exhibits weaker co-movement of regional inflation under the IT regime, with the spatial correlation dropping noticeably after 1998. At first glance, this outcome seems somewhat conflicting with our earlier results that the change in the dynamic behavior of aggregate inflation under the IT regime is mainly driven by 'Services' rather than by 'Commodities'. On closer examination, however, a potential logical explanation comes to the fore. Looking back at Figure 2, we see that services inflation fell into the target range quickly after the adoption of IT and has remained more or less within the range since. To the extent that inflation remains within the target level under the IT regime, regional inflation rates in service sectors are likely to differ across cities as they are heavily influenced by wage costs and rents that are to a large degree determined locally. In contrast, commodities inflation has continued to fluctuate outside the target range after the change in monetary policy regime. This suggests that inflation movements in the commodities sector continued to be influenced by sector-specific global shocks, that would have a homogeneous impact across regions and contribute to co-movement in regional inflation rates in these sectors.

To throw additional light on this issue, we plot in Figure 8 the correlation of city-pair inflation rates against the physical distance between the cities both at the aggregate and disaggregate levels before and after IT adoption. Given the well-established role of geographical distance in market segmentation (e.g., Choi and Choi 2014), it is conceivable that the correlation coefficient between regional inflation rates is negatively associated with physical distance, i.e., the dynamics of inflation are likely to differ more among city-pairs that are farther apart and hence they are likely to have a smaller correlation coefficient for city-level inflation. If IT is successful in establishing a nominal anchor, however, one may posit a weaker association between distance and regional inflation correlation 
Figure 8: Association between Distance (on the horizontal axis) and City Inflation Correlation (on the vertical axis)

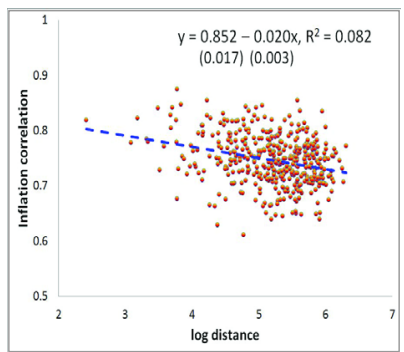

Full sample: All-items

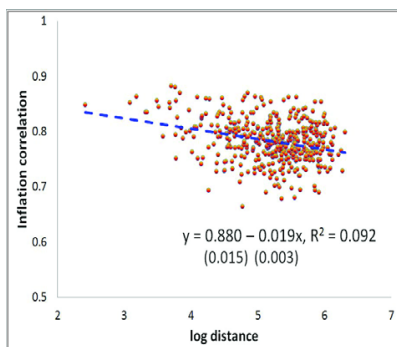

Full sample: Commodities

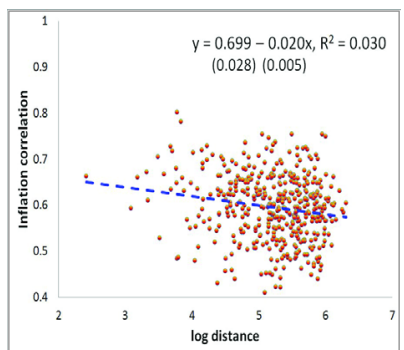

Full sample: Services

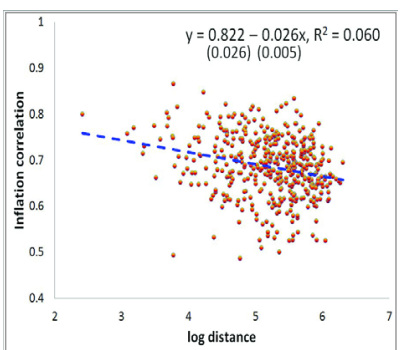

PrelT: All-items

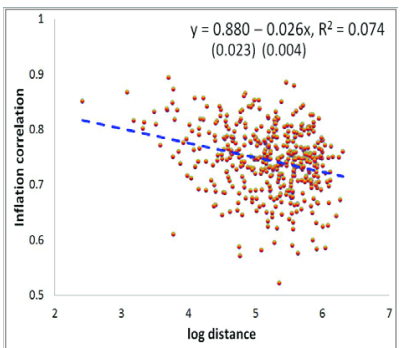

PrelT: Commodities

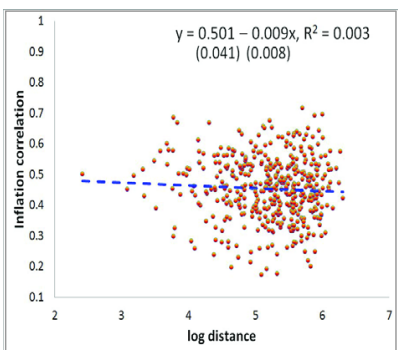

PrelT: Services

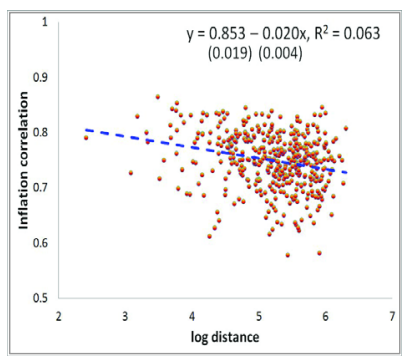

Post-IT: All-items

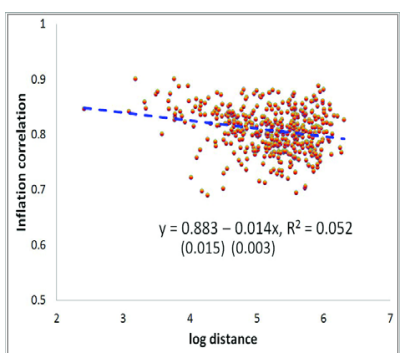

Post-I T: Commodities

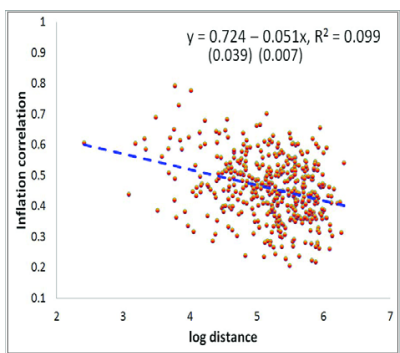

Post-IT: Services

under the IT regime. As is obvious from the plots in Figure 8, city-pair inflation correlation is inversely associated with log distance in both aggregate inflation and the two main sectoral inflation measures. When it comes to the effect of IT on the association, however, we note a clear difference between the two disaggregate items, 'Commodities' and 'Services'. While the slope of the city inflation correlation and distance tradeoff appears to have become flatter in 'Commodities', it got much steeper in 'services' after IT adoption. Put alternatively, geographical distance 


\section{BOK Working Paper No.2015-20 (2015. 07.)}

matters less for city-pair inflation correlation after the IT adoption in 'Commodities' but not in 'Services'. This can be interpreted as saying that spatially apart cities tend to experience more similar dynamics of 'Commodities' inflation after IT adoption, but more heterogeneous dynamics of 'Services' inflation. As such, the effect of IT adoption on the dynamics of regional inflation is quite different across sectors.

Combined together, our results in this section indicate that the increased co-movement in aggregate regional inflation observed after the adoption of IT may not be a direct result of the usual mechanisms associated with the change in the monetary regime. When looking at the disaggregate inflation series, it is apparent the increase in the co-movement is being driven by the commodities sector, in contrast to the rest of our analysis where the changes in the dynamics of services inflation dominated. The bigger impact on services reported in earlier sections is thought to reflect the greater impact of better anchored inflationary expectations on those sectors compared with globally traded commodites whose prices are less influenced by domestic monetary policy. This suggests that there is more to the story behind the change in the degree of co-movement across the regional inflation. If inflationary expectations are better anchored due to IT, then shocks that are common across sectors and regions will be less persistent and so play a smaller role in inflation movements. Therefore, we should not necessarily expect that IT would increase the degree of co-movement across regions. For example, idiosyncratic shocks could lead to a fall in regional co-movement, as inflation rates returned to the common target range. Or, if initial inflation rates differ across regions, then convergence towards a common target could result in a lower degree of co-movement. To obtain a clearer understanding of how IT may have impacted the relative importance of common versus idiosyncratic shocks, we next employ a model that decomposes inflation movements along those lines. 


\section{Common Factor Model Analysis}

In this section, we employ a common factor model framework to investigate whether regional inflation is better explained by nationwide factors than by city-specific factors under IT. The basic idea of a common factor model is to decompose the volatility of city-level inflation into two components: one reflecting nationwide common shocks that affect regions, and the other reflecting idiosyncratic regional shocks that are specific to each region. This decomposition allows us to evaluate the relative importance of aggregate shocks to city specific shocks in explaining the variability of regional inflation. Given that monetary regime change would affect the dynamics of regional inflation mainly through common components, IT adoption would increase the role of the nationwide common component in explaining city-level inflation fluctuations. This increase in the common component can be attributable to more homogeneous, better-anchored inflation expectations under the IT regime due to a stronger commitment of the BOK to a numerical target for inflation. Once inflation expectations are anchored under IT, regional inflation is likely to respond more homogeneously to aggregate shocks, as markets would expect the associated inflation to eventually dampen out with central bank policy offsetting the effects of exogenous disturbances. But again, the role of common factor may differ greatly across sectors.

We consider the following prototypical factor representation, 8 )

$$
\pi_{i t}=a_{i}+\underbrace{\lambda_{i}^{\prime} F_{t}}_{C_{i t}}+e
$$

where $\pi_{i t}$ denotes either the aggregate or a sectoral inflation rate in city $i$ in period $t, a_{i}$ represents an individual fixed effect, $C_{i t}$ is common component, and $e_{i t}$ is an idiosyncratic error associated with idiosyncratic city-specific events or

8) Our approach closely follows the studies by Altissimo et al. (2009) and Reis and Watson (2010) who construct factor models based on sub-aggregate prices without including any other macroeconomic variables as in Boivin et al. (2009). 
Table 4: Share of Common (Aggregate) Shock across Cities before and after IT Adoption

\begin{tabular}{|c|c|c|c|c|c|c|c|c|c|}
\hline \multirow[b]{2}{*}{ Items } & \multicolumn{3}{|c|}{ Full sample } & \multicolumn{3}{|c|}{ Pre-IT } & \multicolumn{3}{|c|}{ Post-IT } \\
\hline & Mean & Min & Max & Mean & Min & Max & Mean & Min & Max \\
\hline All items & 0.756 & 0.656 [CNA] & 0.849 [DGU] & 0.699 & $0.529[\mathrm{CNA}]$ & 0.831 [DGU] & 0.759 & 0.586 [SGN] & $0.839[\mathrm{DJN}]$ \\
\hline Commodities & 0.791 & $0.690[\mathrm{CNA}]$ & 0.879 [DGU] & 0.755 & $0.595[\mathrm{CNA}]$ & 0.887 [DGU] & 0.815 & $0.700[\mathrm{NWN}]$ & $0.873[S W N]$ \\
\hline Services & 0.612 & $0.454[\mathrm{GNJ}]$ & $0.742[\mathrm{DJN}]$ & 0.478 & $0.260[\mathrm{GNJ}]$ & $0.647[\mathrm{ICN}]$ & 0.483 & 0.230 [SGN] & 0.701 [DJN] \\
\hline Agricultural products & 0.747 & $0.658[\mathrm{JJD}]$ & 0.860 [DGU] & 0.570 & $0.364[\mathrm{JIN}]$ & 0.724 [DGU] & 0.794 & 0.705 [JJD] & 0.891 [DGU] \\
\hline Stock products & 0.505 & $0.365[\mathrm{SCN}]$ & 0.670 [SEL] & 0.436 & 0.158 [ULS] & 0.701 [JEN] & 0.540 & 0.389 [MKP] & 0.713 [SEL] \\
\hline Marine products & 0.251 & $0.092[\mathrm{JJD}]$ & $0.488[\mathrm{ICN}]$ & 0.267 & 0.061 [JJD] & $0.577[S W N]$ & 0.234 & $0.079[\mathrm{MKP}]$ & $0.422[\mathrm{ICN}]$ \\
\hline Processed food & 0.703 & $0.595[\mathrm{AND}]$ & 0.869 [SEL] & 0.706 & 0.516 [JJD] & 0.880 [SEL] & 0.672 & 0.571 [DGU] & 0.843 [SEL] \\
\hline Durable goods & 0.750 & $0.554[\mathrm{JIN}]$ & $0.853[\mathrm{PHN}]$ & 0.617 & $0.220[\mathrm{JIN}]$ & $0.792[S W N]$ & 0.799 & $0.652[\mathrm{CCN}]$ & $0.881[\mathrm{BCN}]$ \\
\hline Textile products & 0.796 & 0.620 [GUM] & 0.911 [BSN] & 0.740 & $0.504[\mathrm{BCN}]$ & 0.903 [WNJ] & 0.893 & 0.755 [JJD] & $0.950[\mathrm{BSN}]$ \\
\hline Publications & 0.819 & 0.703 [UJB] & $0.935[\mathrm{GWJ}]$ & 0.730 & $0.548[\mathrm{GUM}]$ & $0.916[\mathrm{GWJ}]$ & 0.974 & $0.951[S G N]$ & $0.989[\mathrm{WNJ}]$ \\
\hline Oils & 0.965 & $0.943[\mathrm{GNG}]$ & $0.983[\mathrm{CHE}]$ & 0.980 & $0.952[\mathrm{GNG}]$ & $0.994[\mathrm{CHE}]$ & 0.939 & $0.902[\mathrm{JJD}]$ & $0.968[\mathrm{BSN}]$ \\
\hline Other industrial products & 0.811 & $0.711[\mathrm{JIN}]$ & 0.891 [GWJ] & 0.739 & $0.569[S W N]$ & 0.891 [DGU] & 0.837 & $0.747[\mathrm{JIN}]$ & $0.921[\mathrm{GWJ}]$ \\
\hline Rental for housing & 0.333 & $0.088[\mathrm{JJD}]$ & 0.689 [DGU] & 0.271 & 0.008 [GUM] & 0.682 [SEL] & 0.253 & $0.000[\mathrm{NWN}]$ & 0.632 [SEL] \\
\hline Public services & 0.668 & 0.422 [YSU] & $0.765[\mathrm{GWJ}]$ & 0.714 & $0.484[\mathrm{SEL}]$ & 0.849 [GUM] & 0.585 & $0.273[\mathrm{YSU}]$ & $0.747[\mathrm{ICN}]$ \\
\hline Eating out & 0.354 & 0.117 [SGN] & 0.611 [SEL] & 0.322 & $0.049[\mathrm{GNJ}]$ & $0.627[\mathrm{SCN}]$ & 0.273 & 0.015 [SGN] & $0.496[\mathrm{SEL}]$ \\
\hline
\end{tabular}

Note: The ‘Pre-IT’ period spans 1990:M1-1998:M3.

measurement error. Note that the common component $\left(C_{i t}\right)$ is the product of $F_{t}$ and $\lambda_{i}$, where the former is the $r \times 1$ vector of common factors $\left(F_{t}\right)$ that captures common sources of variation in city-level inflation driven by aggregate shocks, and the latter are factor loadings that measure the 'sensitivity' of inflation in sector i to the common shocks. In this model, city inflation may exhibit different dynamics due either to different idiosyncratic shocks $\left(e_{i t}\right)$ or to different responses to common aggregate shocks captured by factor loadings $\left(\lambda_{i}\right)$. Before estimation, each sectoral inflation rate is demeaned to remove region specific effects, such as income and population, and is further standardized by dividing by its sample standard deviation to deal with cross sectional heteroskedasticity. Consequently, demeaned standardized inflation rates $\left(\tilde{\pi}_{i t}=\left(\pi_{i t}-\mu_{i}\right) / \sigma_{\pi_{i t}}\right)$ are used to estimate the model based on the principal component method. The 'minimum rule' proposed by Greenaway-McGrevy et al. (2010) for the selection of the number of factors suggest that one factor is sufficient for all sectors under study.

The results from the factor analysis are reported in Table 4, which summarizes the variance decomposition of aggregate inflation as well as sectoral inflation in the pre- and post-IT periods. For each CPI item, we estimate the factor model by using 30 city-level inflation rates so that idiosyncratic component captures 
city-specific component. Table 4 illustrates several interesting points. First, in the aggregate inflation, one common factor can explain about $75 \%$ of the variability of city-level inflation, suggesting considerable commonality across all cities at the aggregate level.9) That is, only one-fourth of regional aggregate inflation volatility can be explained by city-specific factors. At the sectoral level, we notice substantial heterogeneity in the share of the common component across sectors. In the full sample period, more than $96 \%$ of the city-level inflation volatility is explained by the common factor in 'Oils'. By contrast, only $25 \%$ of the variation in city-level inflation is explained by common shocks in 'Marine products'. We also find that the nationwide common factor has significantly different effects across cities. Except for 'Oils', the share of variance explained by the nationwide common factor varies substantially across cities within specific sectors. In 'Rental for housing', for instance, the portion of the common component is merely $8.8 \%$ in Jeju, while it is almost $70 \%$ in Daegu. Second, and more importantly, IT adoption appears to have brought about a change in the relative importance of the common component. Under the IT regime, the importance of the common factor has increased across cities in explaining inflation volatility. In the aggregate inflation series, for example, the explanatory power of the common factor increases slightly from $69.9 \%$ in the pre-IT period to $75.9 \%$ in the post-IT period. The increase in the common component share is consistent with our finding in the previous sections on the stronger co-movements of aggregate city-level inflation after IT adoption. Not surprisingly, the impact of IT on the share of common component is mixed at the sectoral level. Looking first at the coarser breakdown between 'Commodities' and 'Services', we see a significant increase in the relative importance of the common component for 'Commodities', but only a slight change for 'Services'. Within the twelve more finely disaggregate sectoral series,

9) The relatively high common component share looks a bit puzzling at first in view of the growing body of evidence in the literature (e.g., Boivin et al. 2009, Mackowiak et al. 2009) that only a small portion of the variation in sectoral inflation is explained by aggregate common shocks. But, our finding can be easily reconciled with previous evidence because the former looks at the share of the common factor among regional inflation for a given CPI sector, while the latter focuses on the fraction of common factor among sectoral inflation in a given region or economy. Our result on sectoral heterogeneity is indeed in line with the low share of the common factor in sectoral inflation. 
seven see increases after IT adoption while five see declines, echoing the sectoral heterogeneity observed in previous sections. In general, the importance of the common shock has declined in the post-IT period in the sectors related to non-tradable services such as 'Rental for housing' and 'Eating out'.

It is natural to ask, then, what is responsible for the change in the relative importance of the common shocks after IT adoption. Any change in the share of the common component can arise either from changes affecting the common component or from changes affecting the idiosyncratic shocks. Since the monetary policy regime change is related to the common component, however, it seems sensible to concentrate on a change in the common component as the potential driving force behind changes to the shares pre- and post-IT. As stipulated in eq.(3), since the common component of sectoral inflation $\left(C_{i t}\right)$ consists of both the common factor $\left(F_{t}\right)$ and the factor loadings $\left(\lambda_{i}\right)$ that capture the sensitivity of sectoral inflation to the common factor, any changes either in the common factor or in the sensitivity can lead to a change in the common component volatility. Because the common factor is, by definition, common individual city inflation series, we view the change in the sensitivity $\left(\lambda_{i}\right)$ to aggregate shocks as the possible culprit behind the drop in the common share. To investigate this, we implement regression analysis by relating sectoral inflation rates to the estimated common factor augmented with a time-dummy for IT adoption as follows.

$$
\pi_{i t}=\alpha_{i}+\lambda_{1 i} \widehat{F}_{t}+\lambda_{2 i} \widehat{F}_{t} D_{t}+\varepsilon_{i t}
$$

where $\pi_{i t}$ represents the regional inflation rate for city $i$ in time $t, \widehat{F}_{t}$ denotes the common factor estimated from the full sample, and $D_{t}$ is a time dummy variable which takes the value of one for $t>1998: M 3$. This specification allows us to measure the effect of IT adoption on the sensitivity to common factor $\left(F_{t}\right) \cdot{ }^{10}$ )

10) The parameter of interest is $\lambda_{2 i}$ which measures the change in the sensitivity of sectoral inflation to the common factor $\left(F_{t}\right)$ associated with the adoption of IT. Using the properties of the group-mean estimator, $\hat{\lambda}_{2, G M}=(1 / N) \sum_{i=1}^{N} \lambda_{2 i}$, statistical significance of the parameter of interest can be tested based on its sampling distribution of $\sqrt{N}\left(\hat{\lambda}_{2, G M}-\lambda_{2}\right) \rightarrow^{d} N(0, \Sigma)$ where $\Sigma=(1 / N) \sum\left(\hat{\lambda}_{2 i}-(1 / N) \sum \hat{\lambda}_{2 i}\right)^{2}$ 
Table 5: Sensitivity of Sectoral Inflation to Common Factor $\left(F_{t}\right)$

\begin{tabular}{lcc} 
& $\hat{\lambda}_{1, G M}$ & $\hat{\lambda}_{2, G M}$ \\
\hline All items & $0.867 \neq(0.000)$ & $0.000(0.000)$ \\
\hline Commodities & $0.887 \neq(0.000)$ & $0.000^{*}(0.000)$ \\
Services & $0.780 \neq(0.000)$ & $-0.001(0.001)$ \\
\hline Agricultural products & $0.862 \neq(0.000)$ & $0.000(0.001)$ \\
Stock products & $0.704 \neq(0.001)$ & $0.003 \neq(0.001)$ \\
Marine products & $0.488 \neq(0.001)$ & $0.002 \ddagger(0.001)$ \\
Processed food & $0.835 \neq(0.000)$ & $0.002 \ddagger(0.000)$ \\
Durable goods & $0.865 \neq(0.000)$ & $-0.002 \ddagger(0.001)$ \\
Textile products & $0.889 \neq(0.000)$ & $0.002 \neq(0.000)$ \\
Publications & $0.902 \neq(0.000)$ & $0.002 \ddagger(0.000)$ \\
Oils & $0.981 \neq(0.000)$ & $0.000 \dagger(0.000)$ \\
Other industrial products & $0.898 \neq(0.000)$ & $0.001(0.001)$ \\
Rental for housing & $0.569 \neq(0.001)$ & $-0.023 \neq(0.004)$ \\
Public services & $0.815 \neq(0.000)$ & $-0.001^{*}(0.001)$ \\
Eating out & $0.580 \neq(0.001)$ & $0.013 \neq(0.002)$
\end{tabular}

Notes: Regression equation is $\pi_{i t}=\alpha_{i}+\lambda_{1 i} \widehat{F}_{t}+\lambda_{2 i} \widehat{F}_{t} D_{t}+\varepsilon_{i t}$, where $\widehat{F}_{t}$ denotes the estimated common factor from the full sample and $D_{t}$ is a time dummy variable which takes the value of one for $t>1998: M 3 . \quad \hat{\lambda}_{k, G M}=(1 / N) \sum_{i=1}^{N} \lambda_{k, i} \quad$ where $k=1,2$. $\sqrt{N}\left(\hat{\lambda}_{2, G M}-\lambda_{2}\right) \rightarrow^{d} N(0, \Sigma)$ where $\Sigma=(1 / N) \sum\left(\hat{\lambda}_{2 i}-(1 / N) \sum \hat{\lambda}_{2 i}\right)^{2}$. $\neq$ indicates statistical significance at the $1 \%$ error levels.

Table 5 presents the regression results for disaggregate CPI items, along with aggregate inflation. We notice a significant dispersion in the sensitivity to common factor across disaggregate CPI items as the coefficient for $\hat{\lambda}_{1 i}$ ranges from 0.569 in 'Rental for housing' to 0.981 in 'Oils'. This confirms our earlier argument that city-level inflation in some sectors is more responsive to the common factor than in others. Moreover, in the majority of sectors (10 out of 14$), \hat{\lambda}_{2 i}$ takes a positive sign, implying that the sensitivity of city inflation to the common factor has increased after IT adoption as postulated earlier. In the aggregate inflation, however, $\hat{\lambda}_{2 i}$ is positive but statistically insignificant. Taken together, the increase in the common component share under the IT regime can be attributable to the increased sensitivity of city inflation to common shocks in many CPI sectors.

In order to get a sense of magnitudes and to facilitate comparisons across sectors in the entire CPI, we estimate the following factor model by combining all disaggregate CPI sectors, 
Figure 9: Share of Common Component in 12 CPI Items across 30 Cities

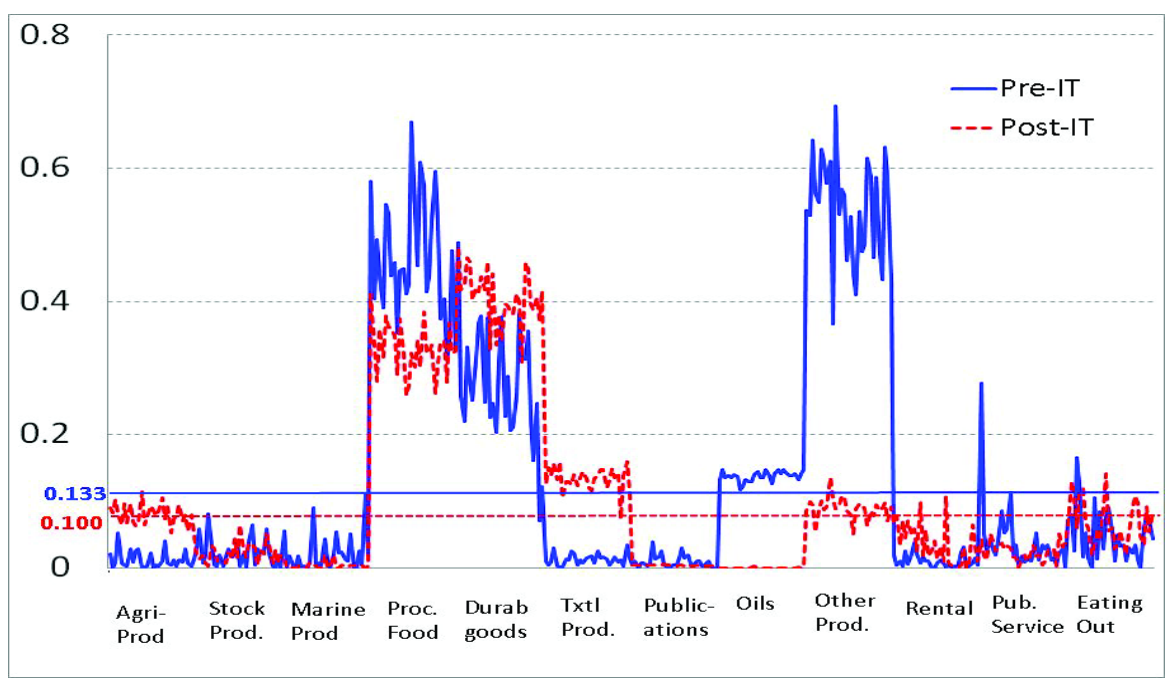

$$
\pi_{i t}^{k}=a+\lambda_{i}^{k^{\prime}} F_{t}+e_{i t}^{k}, \quad k=1, \cdots, 12
$$

where $\pi_{i t}^{k}$ denotes the inflation rate in city $i$ for sector $k$ at time $t$. Figure 9 displays the estimates of the common component share from city inflation for all CPI sectors before (solid line) and after (dotted line) IT adoption. It is important to note that the share of the common component drops drastically to below 15 percent. That is, the common factor explains only a small amount of variability of regional inflation in Korea when all sectors are taken into account. Interestingly the low common factor share estimates are similar to what is found by Boivin et al. (2009) in the U.S. data and by Choi and O'Sullivan (2013) in the Canadian data. And it is in line with the growing empirical literature (e.g. Boivin et al. 2009, Altissimo et al. 2009) that the variance of sectoral inflation is attributable more to sector-specific shocks than to common aggregate shocks. The visual impression from Figure 9 also suggests a heterogeneous contribution of the single common factor to the variance of city-level inflation across CPI sectors. Other than for a few sectors such as 'Agricultural products', 'Durable goods' and 'Textile products', the common component share looks lower under the IT regime when all disaggregate CPI sectors are considered together. In consequence, the overall common 
component share has decreased from 0.133 in the pre-IT period to 0.100 in the post-IT period. The decline in the common component share can be interpreted as saying that sectoral inflation became less responsive to aggregate national macro shocks when inflation expectations became better anchored under the new monetary regime. The decrease in the overall common component share after IT adoption is also in line with the findings by Ciccarelli and Mojon (2005) and Choi and O'Sullivan (2013) that the common factor has less impact in countries with a stronger commitment to price stability.

Overall, the results from the factor model analysis are rather mixed. While IT brought about a greater role for common nationwide shocks for aggregate regional inflation and in many sectors, the importance of common nationwide shocks has decreased under IT when all sectors are combined. Combining these findings with those from the previous section indicates that the better anchoring of expectations under IT does not necessarily lead to more synchronization of regional inflation, possibly due to the belief that the central bank will offset common shocks to return to the inflation target means that those shocks play a smaller role in inflation dynamics.

\section{Impact of IT on Intercity Relative Prices}

Another useful way to evaluate the impact of IT adoption on the dynamics of city-level inflation is to analyze the dynamic behavior of intercity relative prices. To the extent that the new monetary policy regime leads to a reduction in the dispersion of inflation across cities, one may expect that price differences between cities, or intercity relative prices, would be smaller and less persistent under the IT regime. For this reason, it would be intuitive to explore whether relative prices exhibit a faster convergence toward the mean after IT adoption.

Following standard practice in the literature (e.g., Cecchetti et al. 2002, Choi and Matsubara 2007), intercity relative price between cities $i$ and $j$ is constructed as the following log price difference,

$$
q_{i j, t}^{k}=\ln P_{i t}^{k}-\ln P_{j t}^{k}
$$


Figure 10: Empirical Densities of Persistence of Intercity Relative Prices before (dotted line) and after (solid line) IT Adoption
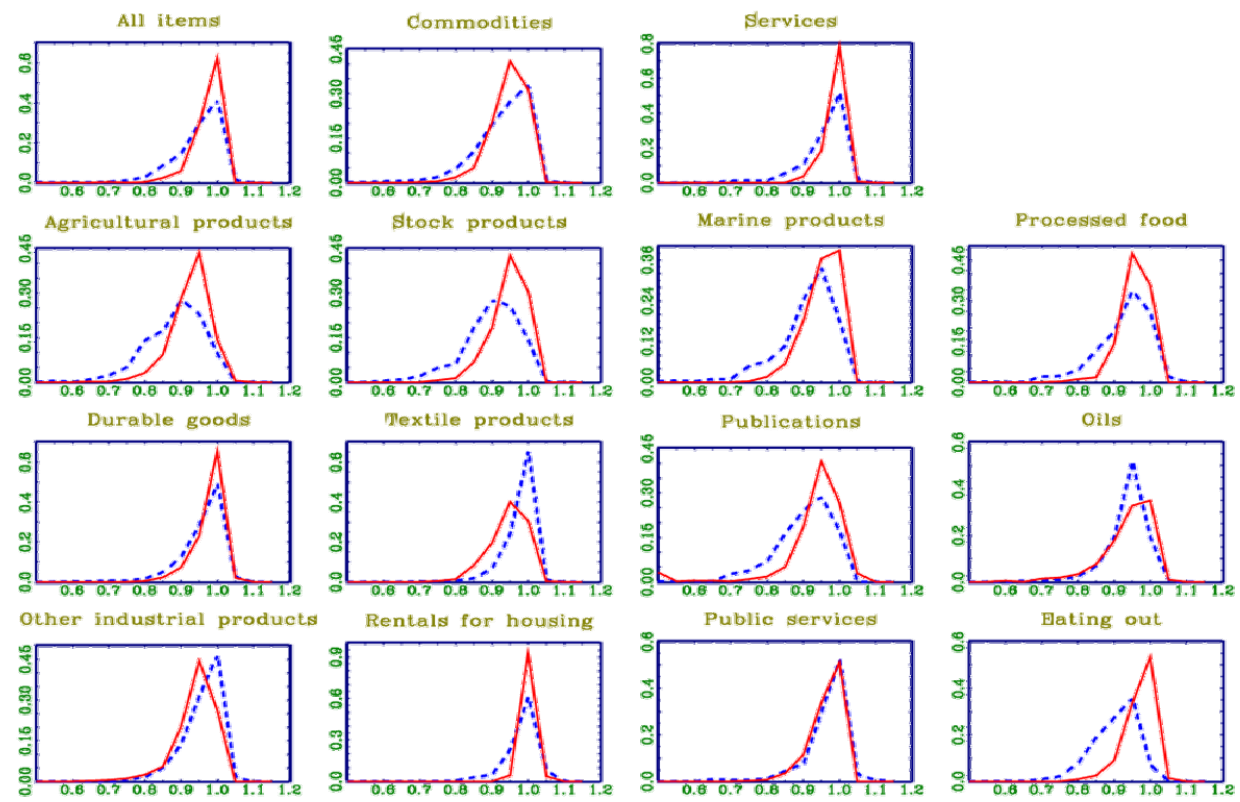

where $P_{h t}^{k}$ denotes consumer price index for $k^{t h}$ sector in city $h$ at time $t$. $q_{i j, t}^{k}=0$ if the price levels in two cities are identical. By setting every city as numeraire rather than fixing a specific city as benchmark, we obtain 435 relative price series $(=(30 \times 29) / 2)$ for each CPI item. For our purpose, it would be informative to examine the stability of cross-city distributions of price differences after IT adoption. A notable shift in the distribution of intercity relative prices after IT adoption indicates a significant effect of the monetary regime change on cross-city price level differences.

Figure 10 provides a visualization of this by plotting the empirical distributions of intercity relative prices from 435 city-pairs in the pre-IT period (dotted line) and under the IT regime (solid line). No clear pattern emerges in terms of changes to these distributions after IT adoption. A moderate leftward shift, which implies a reduction in the price difference between cities under the IT regime, is noticed only in 'Textile products' and 'Other industrial products'. For the others, 


\section{Table 6: Persistence of Intercity Relative Prices}

\begin{tabular}{|c|c|c|c|c|}
\hline & \multicolumn{2}{|c|}{ Pre-IT } & \multicolumn{2}{|c|}{ Post-IT } \\
\hline & Mean & {$[10 \%, 90 \%]$} & Mean & {$[10 \%, 90 \%]$} \\
\hline All items & 0.921 & {$[0.835,0.979]$} & 0.949 & {$[0.905,0.981]$} \\
\hline Commodities & 0.904 & {$[0.806,0.982]$} & 0.922 & {$[0.864,0.973]$} \\
\hline Services & 0.934 & {$[0.859,0.987]$} & 0.965 & {$[0.929,0.990]$} \\
\hline Agricultural products & 0.858 & {$[0.759,0.948]$} & 0.902 & {$[0.838,0.956]$} \\
\hline Stock products & 0.872 & {$[0.769,0.958]$} & 0.921 & {$[0.860,0.968]$} \\
\hline Marine products & 0.884 & {$[0.776,0.963]$} & 0.928 & {$[0.862,0.980]$} \\
\hline Processed food & 0.901 & {$[0.805,0.973]$} & 0.930 & {$[0.881,0.967]$} \\
\hline Durable goods & 0.935 & {$[0.861,0.989]$} & 0.955 & {$[0.903,0.991]$} \\
\hline Textile products & 0.953 & {$[0.902,0.989]$} & 0.920 & {$[0.850,0.973]$} \\
\hline Publications & 0.878 & {$[0.772,0.963]$} & 0.879 & {$[0.839,0.984]$} \\
\hline Oils & 0.913 & {$[0.848,0.958]$} & 0.914 & {$[0.828,0.980]$} \\
\hline Other industrial products & 0.934 & {$[0.864,0.980]$} & 0.915 & {$[0.852,0.969]$} \\
\hline Rental for housing & 0.958 & {$[0.905,0.998]$} & 0.983 & {$[0.962,0.997]$} \\
\hline Public services & 0.940 & {$[0.871,0.985]$} & 0.941 & {$[0.883,0.984]$} \\
\hline Eating out & 0.877 & {$[0.793,0.944]$} & 0.945 & {$[0.893,0.987]$} \\
\hline
\end{tabular}

Notes: Entries represent MUB (median unbiased) estimates for the sum of AR coefficient $(\hat{\beta})$ in $\operatorname{AR}(p)$ model for intercity relative prices $\left(q_{i j, t}\right)$

$$
q_{i j, t}=\alpha+\rho q_{i j, t-1}+\sum_{j=1}^{k} \delta_{j} \Delta q_{i j, t-j}+\varepsilon_{i j, t},
$$

where $q_{i j, t}=p_{i t}-p_{j t}$ and $p_{h t}$ denotes the logarithm of the consumer price indices in city $h$ at time $t$. There are 435 relative prices $(=(30 \times 29) / 2)$ for each CPI item using every city as numeraire.

either no obvious shift (e.g., aggregate CPI and 'Oils') or a slight rightward shift ('Stock prices' and 'Eating out') in the distribution is noticed. It is therefore hard to draw any conclusive inference from our results with regard to the impact of IT adoption on intercity relative prices.

To gain further insight on this issue, we also compare the persistence of relative intercity prices across CPI items before and after IT adoption by employing the sum of autoregressive coefficients (SARC) $(\rho)$ in eq.(1). A faster convergence speed of intercity relative prices after IT adoption implies that shocks affecting sectoral prices die out more quickly under the IT regime. The left-hand panel of Table 6 reports the estimation results from which a meaningful inference can be drawn. Contrary to our prior expectations, persistence of relative prices has not decreased after IT adoption in the vast majority of sectors, nor in aggregate prices. To be specific, the 30-city average persistence of intercity differences in aggregate prices has risen from 0.921 (the corresponding half-life of 8.4 months) to 0.949 (the corresponding half-life of 13.2 months). A faster convergence speed of intercity 
relative prices under the IT regime is noticed in only two sectors, 'Textile products' and 'Other industrial products'. This result appears to support our earlier finding that co-movement in inflation across regions fell after IT for some of the disaggregate series, especially in the 'Services' sector.

\section{Price Stickiness as a Potential Factor behind the Sectoral Heterogeneity}

The core message of our analysis is the heterogeneous responses of sectoral inflation to IT, with the response of city-level inflation to the monetary policy regime change much more pronounced in some sectors than in others. An important question then arises as to what underlying sectoral characteristics might account for the difference in their responses to the policy regime change. From among the rich menu of potential explanations, we consider here a sectoral feature related to nominal frictions that has featured prominently in the literature exploring pricing behavior: the degree of price stickiness. Price stickiness has long been recognized by theoretical and empirical researchers alike as an important mechanism capable of generating persistent and volatile movements in relative prices (e.g., Dornbusch 1976, Bergin and Feenstra 2001). On the theoretical front, macroeconomic models often predict that sticky prices have important implications for both monetary policy and the dynamics of the aggregate price level (e.g. Aoki 2001). On the empirical side, more recent studies offer compelling evidence of sectoral heterogeneity in price stickiness (e.g., Bils and Klenow 2004, Nakamura and Steinsson 2008, Kehoe and Midrigan 2011). Combined together, sectors with differing degrees of price adjustment are likely to respond differently to change in the monetary policy framework, such as adoption of IT. Hence there is good reason to postulate that the varying speed of adjustment of prices across sectors can help explain the different responses of sectoral prices to the monetary policy regime change. In this section, we examine whether and how this sectoral feature is closely associated with the patterns of sectoral inflation observed in the preceding sections. For the measure of price stickiness data for Korea, we borrow the raw data on the duration of unchanged prices from Park and Song (2013) which are reported in Table A.1 in the Appendix. 
Figure 11: Association of Change in Persistence of Intercity Relative Prices with Frequency of Price Change

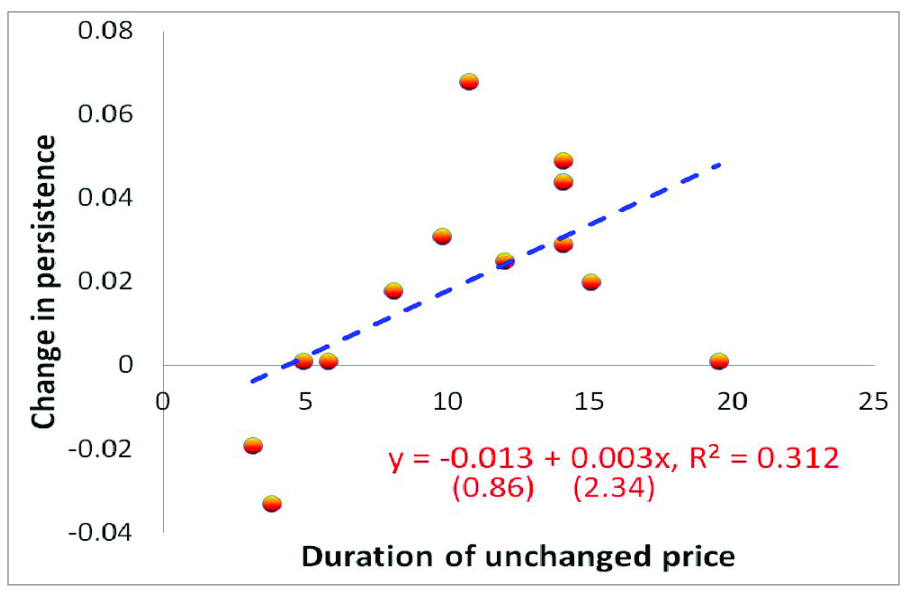

The scatterplot in Figure 11 presents evidence on the role of price stickiness in explaining the heterogeneous response at the sectoral level. Specifically, we plot the duration of unchanged prices against the change in persistence of intercity relative prices after IT adoption as tabulated in Table 6. As illustrated in the plot, there is a clear positive relationship between the two variables, indicating that more sticky price sectors tend to experience a larger increase in the persistence of intercity relative prices after IT adoption. That is, the price difference between two cities tends to persist longer under the IT regime in the sectors where prices are adjusted less frequently. This is consistent with the conventional wisdom that price stickiness leads to more persistent deviations in relative prices from PPP by impeding goods prices from adjusting quickly to shocks (e.g., Kehoe and Midrigan 2011). The evidence on intercity relative prices is rather mixed, however. We find little evidence that IT adoption has exerted a meaningful impact on the city-pair price differences in terms of the level and its persistence. 


\section{IV . Concluding Remarks}

A growing consensus has emerged in the literature regarding the importance of disaggregate analysis in the study of inflation dynamics. Inspired by this, we examined the impact of the adoption of IT on regional inflation dynamics using disaggregate sectoral price data for Korea. Our aims were to assess the regional inflation responses to the adoption of IT and to identify the sectors of the economy that were more sensitive to the change in the monetary regime. Given that heterogeneity of regional inflation dynamics may be due to the segmentation of labor and product markets, it is useful to examine how the heterogeneity of regional inflation differs across sectors before and after the monetary regime change. By looking at the response to IT across different regions for a multitude of sectors, therefore, we attempt to add to empirical findings in the existing literature, allowing us to analyze more precisely the impact of IT on regional inflation.

At the aggregate level, our results in general confirm the findings of previous studies that a change in monetary regime that leads to better anchored inflationary expectations results in lower volatility and persistence in inflation. We also find that such a change leads to convergence of aggregate measures of regional inflation under IT, judging from a lower dispersion of mean inflation and persistence, and a higher share of a nationwide common factor in explaining the variability of aggregate regional inflation. The change in the national monetary policy framework in Korea had significant impact on the dynamics of city-level inflation, with the co-movement of aggregate regional inflation more influenced by a nationwide common factor under IT. By decomposing the fluctuations in aggregate regional inflation into a common and a sector-specific component, we found that about 75 percent of the variance of city-level inflation is explained by a nationwide common factor, although the portion drops to merely 10-13 percent when all CPI sectors are taken into account. More importantly, the common component share has slightly increased after IT adoption, in line with the popular view that the common factor captures aggregate shocks, such as a monetary policy regime change. 
At the sectoral level, however, substantial heterogeneity exists in the response of city inflation rates across disaggregate CPI items, which would have been masked in the analysis at the aggregate level. For most of the changes we observe in the dynamics of regional inflation, we find that the aggregate effects are being driven primarily by sectors that fall into the 'Services' category. We posit that the impact of better anchored inflationary expectations is primarily on the less-traded services sectors of the economy, where the domestic monetary policy framework has a relatively larger influence compared with globally-traded commodities. When it comes to the increased co-movement observed across regions under IT regime, however, it is the 'Commodities' sectors rather than 'Services' that are responsible, probably because services inflation becomes relatively more influenced by local factors once it has stabilized within the target range.

Our interpretation of these findings is that the impact of the monetary regime change in terms of expectation formation is primarily through sectors that are less-tradable - such as services (e.g., 'Rental for housing') rather than globally traded commodities such as 'Oils', whose inflation dynamics reflect global market developments. A rise in the share of common component across cities for commodities sectors is consistent with a more dominant role for these common global shocks in driving the dynamics of these sectors, in which city-specific shocks play a smaller role. We see that regional inflation in these sectors still moves quite a bit outside the IT target range (both above and below) after IT adoption consistent with an important role for factors beyond national monetary policy. This also accords with the greater degree of co-movement observed in these commodity sectors across cities. In contrast, the co-movement of services inflation across cities has fallen after IT adoption, probably because services price are more heavily influenced by local factors like wage and rent.

We see two main policy lessons from this analysis. The first is that a successful implementation of an IT regime may not necessarily result in a greater degree of co-movement in regional inflation as is often perceived. Co-movements may become less synchronized in some sectors even as mean inflation becomes less dispersed and inflation persistence falls. Depending on the sectoral composition of the economy in question, therefore, increased co-movement in aggregate 


\section{$39 \quad$ BOK Working Paper No.2015-20 (2015. 07.)}

inflation across regions may not be observed even though the benefits of IT in anchoring expectations are present. The second lesson stems from the patterns of sectoral heterogeneity in our empirical results. It appears the benefits of IT in aggregate inflation come primarily from the impact on services rather than commodities inflation. As the services sectors in many economies become increasingly dominant, they may help enhance the role of domestic monetary policy framework to impact inflation dynamics and provide somewhat of a counter-balance to the increasingly globalized nature of the markets for many products. But, at the same time, the strength of co-movements among regional inflation rates may decrease once the goal of better anchored inflationary expectations is achieved. 


\section{References}

Altissimo, F., L. Bilke, A. Levin, T. Mathä, and B. Mojon (2006), "Sectoral and Aggregate Inflation Dynamics in the Euro Area," Journal of the European Economic Association, Vol. 4, pp. 585-593.

Altissimo, F., B. Mojon, and P. Zaffaroni (2009), "Can Aggregation Explain the Persistence of Inflation?" Journal of Monetary Economics, Vol. 56, pp. 231-241.

Aoki, K. (2001), "Optimal Monetary Policy Responses to Relative-Price Changes," Journal of Monetary Economics, Vol. 48, pp. 55-80.

Bai, J., and P. Perron (1998), "Estimating and Testing Linear Models with Multiple Structural Changes," Econometrica, Vol. 66(1), pp. 47-78.

Beck, G., K. Hubrich, and M. Marcellino (2009), "Regional Inflation Dynamics within and across Euro Area Countries and a Comparison with the US," Economic Policy, Vol. 24(57), pp. 141-184.

Benati, L. (2008), "Investigating Inflation Persistence across Monetary Regimes," Quarterly Journal of Economics, Vol. 123(3), pp. 1005-1060.

Bergin, P., and R. C. Feenstra (2001), "Pricing to Market, Staggered Contracts, and Real Exchange Rate Persistence," Journal of International Economics, Vol. 54(2), pp. 333-359.

Bilke, L. (2005), "Break in the Mean and Persistence of Inflation - A Sectoral Analysis of French CPI," ECB Working Paper, No. 463, European Central Bank.

Bils, M., and P. J. Klenow (2004), "Some Evidence on the Importance of Sticky Prices," Journal of Political Economy, Vol. 112, pp. 947-985.

Boivin, J., M. P. Giannoni, and I. Mihov (2009), "Sticky Prices and Monetary Policy: Evidence from Disaggregated US Data," American Economic Review, Vol. 99(1), pp. 350-384. 


\section{$41 \quad$ BOK Working Paper No.2015-20 (2015. 07.)}

Carlino, G., and R. DeFina (1998), "The Differential Regional Effects of Monetary Policy," Review of Economics and Statistics, Vol. 92(3), pp. 572-587.

Carvalho, C., and F. Nechio (2011), "Aggregation and the PPP Puzzle in a Sticky-Price Model," American Economic Review, Vol. 101, pp. 2391-2424.

Cecchetti, S. G., N. C. Mark, and R. Sonora (2002), "Price Index Convergence among United States Cities," International Economic Review, Vol. 43, pp. 1081-1099.

Choi, C. Y. (2010), "Reconsidering the Relationship between Inflation and Relative Price Variability," Journal of Money, Credit and Banking, Vol. 42, pp. 769-98.

Choi, C. Y., and H. Choi (2014), "Does Distance Reflect more than Transport Costs?" Economics Letters, Vol. 125(1), pp. 82-86.

Choi, C. Y., Y. S. Kim, and R. O'Sullivan (2011), "Inflation Targeting (IT) and Relative Price Variability (RPV): What Difference Does IT Make?" Southern Economic Journal, Vol. 77(4), pp. 934-957.

Choi, C. Y., and K. Matsubara (2007), "Heterogeneity in the Persistence of Relative Prices: What Do the Japanese Cities Tell Us?" Journal of the Japanese and International Economics, Vol. 21, pp. 260-286.

Choi, C. Y., and R. O'Sullivan (2013), "Heterogeneous Response of Disaggregate Inflation to Monetary Policy Regime Change: The Role of Price Stickiness," Journal of Economic Dynamics and Control, Vol. 37(9), pp. 1814-1832.

Ciccarelli, M., and M. Mojon (2010), "Global Inflation," Review of Economics and Statistics, Vol. 92(3), pp. 524-535.

Clark, T. E. (2006), "Disaggregate Evidence on the Persistence of Consumer Price Inflation," Journal of Applied Econometrics, Vol. 21(5), pp. 563-587.

Dornbusch, R. (1976), "Expectations and Exchange Rate Dynamics," Journal of Political Economy, Vol. 84(6), pp. 1161-1176. 
Erceg, C. J., and A. T. Levin (2003), "Imperfect Credibility and Inflation Persistence," Journal of Monetary Economics, Vol. 50(4), pp. 915-944.

Greenaway-McGrevy, R., C. Han, and D. Sul (2010), "The Role of Standardization in the Estimation of Common Factors," Mimeo, University of Texas at Dallas.

Hansen, B. (1999), "The Grid Bootstrap and the Autoregressive Model," Review of Economics and Statistics, Vol. 81(4), pp. 594-607.

Kehoe, P. J., and V. Midrigan (2011), "Prices Are Sticky after all," Staff Report 413, Research Department, Federal Reserve Bank of Minneapolis.

Kim, S., and Y. C. Park (2006), "Inflation Targeting in Korea: A Model of Success?” BIS Papers, No. 31, Bank for International Settlements.

Kozicki, S., and P. A. Tinsley (2001), "Term Structure Views of Monetary Policy under Alternative Models of Agent Expectations," Journal of Economic Dynamics and Control, Vol. 25, pp. 149-184.

Levin, A. T., and J. M. Piger (2004), "Is Inflation Persistence Intrinsic in Industrial Economies?" ECB Working Paper, No. 334, European Central Bank.

Lunnemann, P., and T. Matha (2004), "How Persistent in Disaggregate Inflation? An analysis across EU15 countries and HICP sub-indices," ECB Working Paper, No. 466, European Central Bank.

Maćkowiak, B., E. Moench, and M. Wiederholt (2009), "Sectoral Price Data and Models of Price Setting," Journal of Monetary Economics, Vol. 56, pp. S78-S99.

Meller, B., and D. Nautz (2009), "The Impact of the European Monetary Union on Inflation Persistence in the Euro Area," Discussion Paper, No. 2009-037, Humboldt-Universitat zu Berlin. 


\section{$43 \quad$ BOK Working Paper No.2015-20 (2015. 07.)}

Mishkin, F. S., and K. Schmidt-Hebbel (2007), "Does Inflation Targeting Make a Difference?" NBER Working Paper, No. 12876, National Bureau of Economic Research.

Nakamura, E., and J. Steinsson (2008), "Five Facts about Prices: A Reevaluation of Menu Cost Models," Quarterly Journal of Economics, Vol. 123, pp. 1415-64.

Orphanides, A., and J. C. Williams (2005), "The Decline of Activist Stabilization Policy: Natural Rate Misperceptions, Learning, and Expectations," Journal of Economic Dynamics and Control, Vol. 29(11), pp. 1927-1950.

Park, C.-G., and S. Song, S. (2013), "Price Rigidity Analysis at Individual Firm Level: Based on 2012 Survey Data," BOK Working Paper, No. 2013-16, The Bank of Korea (in Korean).

Reis, R., and M. W. Watson (2010), "Relative Goods' Prices, Pure Inflation, and the Phillips Correlation," American Economic Journal: Macroeconomics, Vol. 2, pp. $128-157$.

Stock, J. H., and M. W. Watson (2010), "The Evolution of National and Regional Factors in U.S. Housing Construction," in J. R. Bollerslev, T. and M. Watson, eds, Volatility and Time Series Econometrics: Essays in Honor of Robert Engle, Oxford University Press.

Tillmann, P. (2013), "Inflation Targeting and Regional Inflation Persistence: Evidence from Korea," Pacific Economic Review, Vol. 18(2), pp. 147-161. 


\section{Appendix: Data Description}

\section{Table A.1: Data Description by CPI Items}

\begin{tabular}{|rlrr|r}
\hline No. & Items & Weight & Stickiness & Included items \\
\hline 0 & All items & 1000.0 & 9.039 & All 481 items (commodities plus services) \\
\hline 1 & Commodities & 453.2 & 8.085 & 327 items \\
\hline 2 & Services & 546.8 & 9.812 & 154 items \\
\hline 3 & Agricultural products & 44.1 & 14.068 & 51 items including grain, fruit, and vegetable \\
\hline 4 & Stock products & 22.2 & 14.068 & 6 items including beef, pork, chicken, egg, honey \\
5 & Marine products & 11.3 & 14.068 & 14 items including fresh fish, dried squid, laver, seaweed \\
6 & Processed food & 71.8 & 14.068 & 73 items including flour, noodle, cereal, canned fruits, spirits \\
7 & Durable goods & 51.6 & 15.035 & 48 items including eletronics, cars, personal ornaments \\
8 & Textile products & 58.3 & 3.820 & 27 items including clothing, bedding, curtain \\
9 & Publications & 7.9 & 5.806 & 10 items including textbooks, newspaper, magazine \\
10 & Oils & 56.7 & 19.545 & 6 items including gasoline, light oil \\
11 & Other industrial products & 53.7 & 3.141 & 65 items including cigarette, shoes, utencils \\
12 & Rental for housing & 92.8 & 11.992 & 2 items including deposit money for the lease, monthly rent \\
13 & Public services & 142.6 & 4.936 & 29 items including public service fee, transportation fee \\
14 & Eating out & 119.0 & 10.735 & 38 items including restaurant menus, franchise food prices \\
\hline
\end{tabular}

Note: 'Stickiness' denotes the mean duration of unchanged prices calculated based on Park and Song (2013).

\section{Table A.2: Data Description by Cities}

\begin{tabular}{|c|c|c|c|c|c|}
\hline \multirow[t]{2}{*}{ Cities } & \multirow[t]{2}{*}{ Abb. } & \multirow{2}{*}{$\begin{array}{c}\text { Population } \\
(2014)\end{array}$} & \multirow{2}{*}{$\begin{array}{l}\text { Income } \\
(2010)\end{array}$} & \multicolumn{2}{|c|}{ Distance from Seoul (km) } \\
\hline & & & & Railroad & Highway \\
\hline All cities & ALL & 46,002 & 23,717 & - & - \\
\hline Andong & AND & 180 & 14,952 & 256.4 & 362.5 \\
\hline Boryeong & BOR & 114 & 25,448 & 183.6 & 177.4 \\
\hline Bucheon & $\mathrm{BCN}$ & 780 & 14,914 & 21.2 & 23.9 \\
\hline Busan & BSN & 3,654 & 17,544 & 423.8 & 416.1 \\
\hline Cheonan & CNA & 431 & 31,795 & 96.0 & 75.9 \\
\hline Cheongju & $\mathrm{CHE}$ & 581 & 17,463 & 136.0 & 110.9 \\
\hline Chuncheon & $\mathrm{CCN}$ & 248 & 15,793 & 99.4 & 94.3 \\
\hline Chungju & $\mathrm{CHU}$ & 204 & 19,519 & 207.3 & 108.6 \\
\hline Daegu & DGU & 2,432 & 14,653 & 293.1 & 293.9 \\
\hline Daejeon & DJN & 1,326 & 17,725 & 159.8 & 144.1 \\
\hline Gangneung & GNG & 223 & 15,184 & 413.8 & 213.7 \\
\hline Gumi & GUM & 341 & 63,238 & 238.9 & 243.7 \\
\hline Gunsan & GSN & 267 & 28,524 & 229.0 & 225.2 \\
\hline Gwangju & GWJ & 1,328 & 17,147 & 349.6 & 299.1 \\
\hline Gyeongju & GNJ & 268 & 26,042 & 402.2 & 347.8 \\
\hline Incheon & $\mathrm{ICN}$ & 2,379 & 21,602 & 27.0 & 23.9 \\
\hline Jeju-do & JJD & 519 & 18,452 & 446 & 446 \\
\hline Jeonju & JEN & 593 & 12,667 & 265.3 & 216.9 \\
\hline Jinju & JIN & 334 & 16,581 & 450.7 & 315.0 \\
\hline Mokpo & MKP & 247 & 13,020 & 404.4 & 370.8 \\
\hline Namwon & NWN & 97 & 18,394 & 319.3 & 287.6 \\
\hline Pohang & $\mathrm{PHN}$ & 501 & 34,491 & 143.2 & 358.8 \\
\hline Seongnam & SGN & 841 & 17,824 & 33.4 & 23.7 \\
\hline Seoul & SEL & 10,070 & 28,204 & - & - \\
\hline Suncheon & $\mathrm{SCN}$ & 261 & 17,789 & 385.4 & 331.2 \\
\hline Suwon & SWN & 895 & 18,262 & 41.5 & 23.7 \\
\hline Uijeongbu & UJB & 332 & 12,834 & 31.2 & 23.7 \\
\hline Ulsan & ULS & 983 & 55,203 & 372.1 & 390.2 \\
\hline Wonju & WNJ & 263 & 16,662 & 112.0 & 109.5 \\
\hline Yeosu & YSU & 294 & 69,579 & 420.2 & 336.3 \\
\hline
\end{tabular}

Notes: Population is in thousand people. Distance between Seoul and Jeju-Do is the distance between Gimpo airport and Jeju airport. 'income' is the per capita gross regional product in thousand Korean won. 


\section{$45 \quad$ BOK Working Paper No.2015-20 (2015. 07.)}

Table A.3: Weights of CPI Items across Cities

\begin{tabular}{|c|c|c|c|c|c|c|c|c|c|c|c|c|c|c|c|}
\hline & All & omm. & Serv. & Item3 & Item4 & ltem5 & Item6 & Item7 & ltem8 & Item9 & Item10 & Item11 & Item12 & Item13 & liem14 \\
\hline ALL & 1000 & 453.2 & 546.8 & 44.1 & 22.2 & 11.3 & 71.8 & 51.6 & 58.3 & 7.9 & 56.7 & 53.7 & 92.8 & 142.6 & 192.4 \\
\hline AND & 1000 & 508.2 & 491.8 & 48.7 & 23.8 & 16.4 & 76.3 & 56.6 & 59.4 & 7.5 & 83.7 & 59.5 & 45.6 & 142.0 & 184.8 \\
\hline BOR & 1000 & 512.7 & 487.3 & 46.3 & 24.4 & 14.7 & 76.6 & 74.7 & 61.1 & 7.1 & 76.1 & 56.8 & 59.5 & 140.0 & 173.8 \\
\hline $\mathrm{BCN}$ & 1000 & 438.4 & 561.6 & 40.6 & 21.2 & 8.3 & 70.7 & 49.2 & 56.9 & 8.1 & 56.2 & 53.2 & 102.5 & 136.0 & 209.3 \\
\hline BSN & 1000 & 464.3 & 535.7 & 49.6 & 21.6 & 17.5 & 78.6 & 51.2 & 58.1 & 7.5 & 46.6 & 54.7 & 62.2 & 154.4 & 182.7 \\
\hline CNA & 1000 & 512.7 & 487.3 & 46.3 & 24.4 & 14.7 & 76.6 & 74.7 & 61.1 & 7.1 & 76.1 & 56.8 & 59.5 & 140.0 & 173.8 \\
\hline CHE & 1000 & 504.6 & 495.4 & 47.0 & 25.7 & 8.5 & 73.5 & 65.7 & 63.0 & 8.0 & 78.5 & 56.7 & 51.2 & 140.6 & 182.5 \\
\hline $\mathrm{CCN}$ & 1000 & 517.7 & 482.3 & 49.1 & 24.7 & 10.1 & 76.6 & 65.3 & 61.0 & 7.6 & 87.3 & 61.4 & 54.0 & 145.9 & 176.7 \\
\hline $\mathrm{CHU}$ & 1000 & 504.6 & 495.4 & 47.0 & 25.7 & 8.5 & 73.5 & 65.7 & 63.0 & 8.0 & 78.5 & 56.7 & 51.2 & 140.6 & 182.5 \\
\hline DGU & 1000 & 460.1 & 539.9 & 44.6 & 23.2 & 12.3 & 75.8 & 41.1 & 61.0 & 9.0 & 61.2 & 55.0 & 66.4 & 145.1 & 192.7 \\
\hline DJN & 1000 & 484.6 & 515.4 & 45.1 & 23.2 & 9.0 & 73.2 & 58.9 & 62.6 & 8.7 & 62.4 & 58.2 & 81.7 & 134.0 & 185.9 \\
\hline GNG & 1000 & 517.7 & 482.3 & 49.1 & 24.7 & 10.1 & 76.6 & 65.3 & 61.0 & 7.6 & 87.3 & 61.4 & 54.0 & .9 & 176.7 \\
\hline GUM & 1000 & 508.2 & 491.8 & 48.7 & 23.8 & 16.4 & 76.3 & 56.6 & 59.4 & 7.5 & 83.7 & 59.5 & 45.6 & 142.0 & 184.8 \\
\hline GSN & 1000 & 507.9 & 492.1 & 53.0 & 22.5 & 13.1 & 68.9 & 60.4 & 66.9 & 9.3 & 77.7 & 56.2 & 47.1 & 42.0 & 201.7 \\
\hline GWJ & 1000 & 472.3 & 527.7 & 46.1 & 23.0 & 14.6 & 67.7 & 54.7 & 63.3 & 10.2 & 61.1 & 56.2 & 56.5 & 158.5 & 198.2 \\
\hline GNJ & 1000 & 508.2 & 491.8 & 48.7 & 23.8 & 16.4 & 76.3 & 56.6 & 59.4 & 7.5 & 83.7 & 59.5 & 45.6 & 142.0 & 184.8 \\
\hline $\mathrm{ICN}$ & 1000 & 445.1 & 554.9 & 44.1 & 21.9 & 9.7 & 75.1 & 49.4 & 56.3 & 6.8 & 45.7 & 54.2 & 85.9 & 146.6 & 194.4 \\
\hline JJD & 1000 & 488.3 & 511.7 & 42.0 & 23.1 & 13.7 & 81.3 & 71.6 & 51.1 & 7.7 & 87.3 & 60.9 & 49.1 & .9 & 181.3 \\
\hline JEN & 1000 & 507.9 & 492.1 & 53.0 & 22.5 & 13.1 & 68.9 & 60.4 & 66.9 & 9.3 & 77.7 & 56.2 & 47.1 & 142.0 & 201.7 \\
\hline JIN & 1000 & 488.3 & 511.7 & 42.6 & 20.7 & 16.2 & 78.7 & 56.2 & 61.3 & 8.6 & 75.6 & 59.7 & 59.6 & 142.4 & 181.1 \\
\hline MKP & 1000 & 509.7 & 490.3 & 50.1 & 24.5 & 21.1 & 73.5 & 61.1 & 67.7 & 7.3 & 78.3 & 59.4 & 38.6 & 3 & 188.4 \\
\hline NWN & 1000 & 507.9 & 492.1 & 53.0 & 22.5 & 13.1 & 68.9 & 60.4 & 66.9 & 9.3 & 77.7 & 56.2 & 47.1 & 142.0 & 201.7 \\
\hline PHN & 1000 & 508.2 & 491.8 & 48.7 & 23.8 & 16.4 & 76.3 & 56.6 & 59.4 & 7.5 & 83.7 & 59.5 & 45.6 & 142.0 & 184.8 \\
\hline SGN & 1000 & 438.4 & 561.6 & 40.6 & 21.2 & 8.3 & 70.7 & 49.2 & 56.9 & 8.1 & 56.2 & 53.2 & 102.5 & 136.0 & 209.3 \\
\hline SEL & 1000 & 403.5 & 596.5 & 41.7 & 21.6 & 9.1 & 66.6 & 43.0 & 53.6 & 7.2 & 36.3 & 47.9 & 150.1 & 143.6 & 187.9 \\
\hline SCN & 1000 & 509.7 & 490.3 & 50.1 & 24.5 & 21.1 & 73.5 & 61.1 & 67.7 & 7.3 & 78.3 & 59.4 & 38.6 & 151.3 & 188.4 \\
\hline SWN & 1000 & 438.4 & 561.6 & 40.6 & 21.2 & 8.3 & 70.7 & 49.2 & 56.9 & 8.1 & 56.2 & 53.2 & 102.5 & 136.0 & 209.3 \\
\hline UJB & 1000 & 438.4 & 561.6 & 40.6 & 21.2 & 8.3 & 70.7 & 49.2 & 56.9 & 8.1 & 56.2 & 53.2 & 102.5 & 136.0 & 209.3 \\
\hline ULS & 1000 & 474.8 & 525.2 & 39.7 & 21.0 & 13.0 & 68.3 & 70.9 & 61.9 & 6.9 & 64.4 & 56.1 & 58.9 & 134.6 & 193.2 \\
\hline WNJ & 1000 & 517.7 & 482.3 & 49.1 & 24.7 & 10.1 & 76.6 & 65.3 & 61.0 & 7.6 & 87.3 & 61.4 & 54.0 & 145.9 & 176.7 \\
\hline YSU & 1000 & 509.7 & 490.3 & 50.1 & 24.5 & 21.1 & 73.5 & 61.1 & 67.7 & 7.3 & 78.3 & 59.4 & 38.6 & 151.3 & 188.4 \\
\hline
\end{tabular}

Note: See Table A.1 for the descriptions of CPI items. 


\title{
$<$ Abstract in Korean $>$
}

\section{통화정책 운영체제 변화가 지역별·부문별 인플레이션 동학에 미치는 영향 분석}

\author{
최 치 영*, 이 주 용**, Róisín O’Sullivan***
}

본 연구에서는 우리나라의 인플레이션 타겟팅 제도 도입이 지역별 인플레이션 동학에 미치는 영향을 부문별로 세분화된 물가지수 자료를 이용하여 분석하였다. 먼저 지역별 총지수 인플레이션을 살펴보면 기존 문헌에서와 같이 인플레이션 타겟팅 제도 도입 이후 인플레이션 평균, 변동성 및 지속성이 전도시에서 하락한 것으로 나타났다. 또한 지역별 인플레이션 수준의 지역간 편차는 줄어들고 지역간 동조화는 확대된 것으로 나타났다.

다음으로 지역별 및 부문별로 세분화된 인플레이션을 살펴보면 총지수 인플레이션의 움직임과는 다른 특징을 찾아볼 수 있다. 첫째, 인플레이션 타겟팅 제도 도입 이후 총지수 인플레이션의 안정화는 상품지수 인플레이션보다 서비스지수 인플레이션의 하향 안정화에 크게 힘입은 것으로 나타났다. 이는 국내 통화정책이 글로벌 환경의 영향을 많이 받는 교역재보다는 서비스 등 비교역재 가격의 변화를 통해 인플레이션 기대를 정착시키기 때문인 것으로 추정된다.

둘째, 인플레이션 타겟팅 제도 도입 이후 지역별 인플레이션의 동조화가 강화된 것으로 나타났으며, 이러한 현상은 서비스지수 보다는 상품지수 인플레이션의 동조화 확대에 주로 기인한다. 이는 서비스지수 인플레이션이 주로 지역적인 요소의 영향을 받아 다양한 움직임을 보인데 반해 상품지수 인플레이션은 글로벌 상품시장의 변동에 따라 유사한 움직임을 보였기 때문인 것으로 추정된다. 이러한 현상은 새로운 통화정책 운영체제가 가격 경직성이 큰 서비스 부문 등을 통해 큰 영향을 미치는 데 따른 것으로 설명될 수 있다.

핵심 주제어: 지역별 인플레이션, 인플레이션 타겟팅, 인플레이션 동학, 이질성, 부문별 인플레이션

JEL Classification: E31, E52, E58

\footnotetext{
* University of Texas at Arlington 경제학과 교수

** 한국은행 경제연구원 국제경제연구실 전문연구원

*** Smith College 경제학과 교수
}

이 연구내용은 집필자의 개인의견이며 한국은행의 공식견해와는 무관합니다. 따라서 본 논문의 내용을 보도 하거나 인용할 경우에는 집필자명을 반드시 명시하여 주시기 바랍니다. 